\title{
17. DISTRIBUTION, CHEMICAL CHARACTERISTICS, AND ORIGIN OF ASH LAYERS FROM ODP LEG 104, VØRING PLATEAU, NORTH ATLANTIC ${ }^{1}$
}

\author{
A. Desprairies, ${ }^{2}$ R.C. Maury, ${ }^{3}$ J.-L. Joron, ${ }^{4}$ M. Bohn, ${ }^{3}$ and P. Tremblay ${ }^{2}$
}

\begin{abstract}
Forty-five volcanic ash horizons cored at Sites 642,643 , and 644 on the Vøring Plateau and ranging in age from early Miocene to Pleistocene, are discussed in terms of their magmatic features as well as their diagenetic evolution. Most of these layers, some centimeters thick, are mainly made of fresh rhyolitic glass. Twenty-five percent of the ash layers, however, contain variable amounts of more basic glass shards, ranging in composition from $\mathrm{Mg}$-rich tholeiites to icelandites through $\mathrm{Mg}$-poor basalts, ferrobasalts, and tholeiitic andesites, and are commonly associated with rhyolitic shards.

Many chemically heterogeneous ash layers show bimodal acidic (rhyolites to icelandites) - basic (Mg-rich basalts to ferrobasalts) frequency distributions of the glass shards; intermediate compositions are not simple mixtures between acidic and basic endmembers. We suggest these ash layers result from the ejection of the upper (rhyolitic) to intermediate (ferrobasaltic) levels of density-stratified magma chambers intruded by ascending basaltic magmas, as exemplified by several Quaternary Icelandic explosive eruptions. The overall characteristics of the chemical trends of glass shards from heterogeneous ash layers are typically tholeiitic, with a strong increase of total iron and $\mathrm{TiO}_{2}$ at the level of intermediate compositions. Major and trace element data on bulk ash layers indicate that all the tephra of bimodal composition, as well as most of Neogene rhyolitic ash levels (low-K type), belong to LREE-enriched tholeiitic series. However, some Miocene rhyolitic ash levels (high-K type) show distinct geochemical features and are probably derived from other sources.

The volcanic glass alteration patterns have no relationship with the ages of the deposits, and are different for acid and basic glasses. The most common alteration process leads to the formation of iron-beidellite-type smectites through loss of $\mathrm{Si}$ and alkalis from silicic glasses and loss of $\mathrm{Si}, \mathrm{Mg}, \mathrm{Fe}$ from basic glasses. Another kind of alteration, observed in lower Miocene ash layers, leads to glauconite formation through the development of iron-rich smectites.

The frequency of ash layer occurrence with time indicates two apparent maxima of volcanic activity, an early one at the early-middle Miocene boundary (16 to $14 \mathrm{Ma}$ ) and another one in the late Miocene ( 8 to $7 \mathrm{Ma})$. Iceland is the most likely source for all the chemically heterogeneous ash layers as well as the low-K rhyolitic ash levels belonging to these two major episodes. Other subaerial sources, possibly at rifted margins (East Greenland, Jan Mayen Ridge), are required for the high-K rhyolitic ash horizons.
\end{abstract}

\section{INTRODUCTION}

The two main objectives of ODP Leg 104 were to study the origin and composition of the Norwegian Vøring Plateau marginal high and to investigate the Cenozoic paleoenvironment of the Norwegian Sea. Sediments sampled at three sites drilled along a traverse across the Vøring margin (Fig. 1), together with the data gathered during the DSDP Leg 38 document a detailed geological history of the Vøring Plateau (Eldholm, Thiede, Taylor, et al., 1987). A significant result of this coring was identification of abundant tephra horizons within the sedimentary sequences, recording Neogene to Quaternary volcanic activity.

Ash layers of Eocene to Pleistocene age were previously recovered on the Vøring Plateau (DSDP Leg 38, Sites 338-343) as well as elsewhere in the North Atlantic: Iceland-Faeroe Ridge and Norway Basin (Leg 38, Sites 336-337 and 352); Rockall Plateau (Leg 48, Sites 403-404, and Leg 81, Sites 552, 553, and 555); Reykjanes Ridge (Leg 49, Sites 407-409); Iceland Plateau and Jan Mayen Ridge (Leg 38, Sites 346-350). Donn and Ninkovich (1980) and Sigurdsson and Loebner (1981) attempted to establish the history of explosive volcanism associated with the

${ }^{1}$ Eldholm, O., Thiede, J., Taylor, E., et al., 1989. Proc. ODP, Sci. Results, 104: College Station, TX (Ocean Drilling Program).

2 Université de Paris-Sud, Bât. 504, 91405, Orsay, France.

3 Université de Bretagne Occidentale, G.I.S. "Océanologie et Géodynamique", 6, avenue Le Gorgeu, 29287 BREST, France.

4 Centre D'Etudes Nucléaires de Saclay, Laboratoire P. Süe, CNRS-CEA Saclay, B.P. 2, 91190 GIF-SUR-YVETTE, France. rifting and opening of the Norwegian and Greenland Seas using available piston and DSDP cores. According to these authors, the frequencies of ash layers indicate four major volcanic episodes: middle Eocene, Middle Oligocene, lower to middle Miocene, and Pliocene-Pleistocene ages. The two major events occurred during middle Eocene and Pliocene (Donn and Ninkovich, 1980), but these estimates of temporal variation are subject to uncertainties due to the poor recovery from many DSDP Sites.

Chemical analyses of North Atlantic tephra show that Cenozoic explosive volcanism produced two major compositional series: a low-potash series ranging from basalts to rhyolites and a high-potash series ranging from trachytes to alkali rhyolites often associated with comendites (Sigurdsson and Loebner, 1981). According to these authors, the two compositional series have coexisted during the four major episodes of explosive volcanism and result from subaerial igneous activity either at rifted margins (East Greenland and continental Jan Mayen Ridge) or on elevated parts of active mid-ocean ridges (Iceland-Faeroe Ridge, Iceland Platform). Donn and Ninkovich (1980), however, relate all the Cenozoic ash layers to subaerial volcanism of Icelandic origin.

The present study deals with the frequency, magmatic evolution, and diagenetic evolution of the ODP Leg 104 tephra from the three drilled sites. For comparison and to tentatively identify the volcanic sources in the North Atlantic, we added new data on some pyroclastic deposits of Eocene age recovered during DSDP Leg 81 on the Rockall Plateau (Roberts, Schnitker, et al., 1984; Morton and Keene, 1984). 


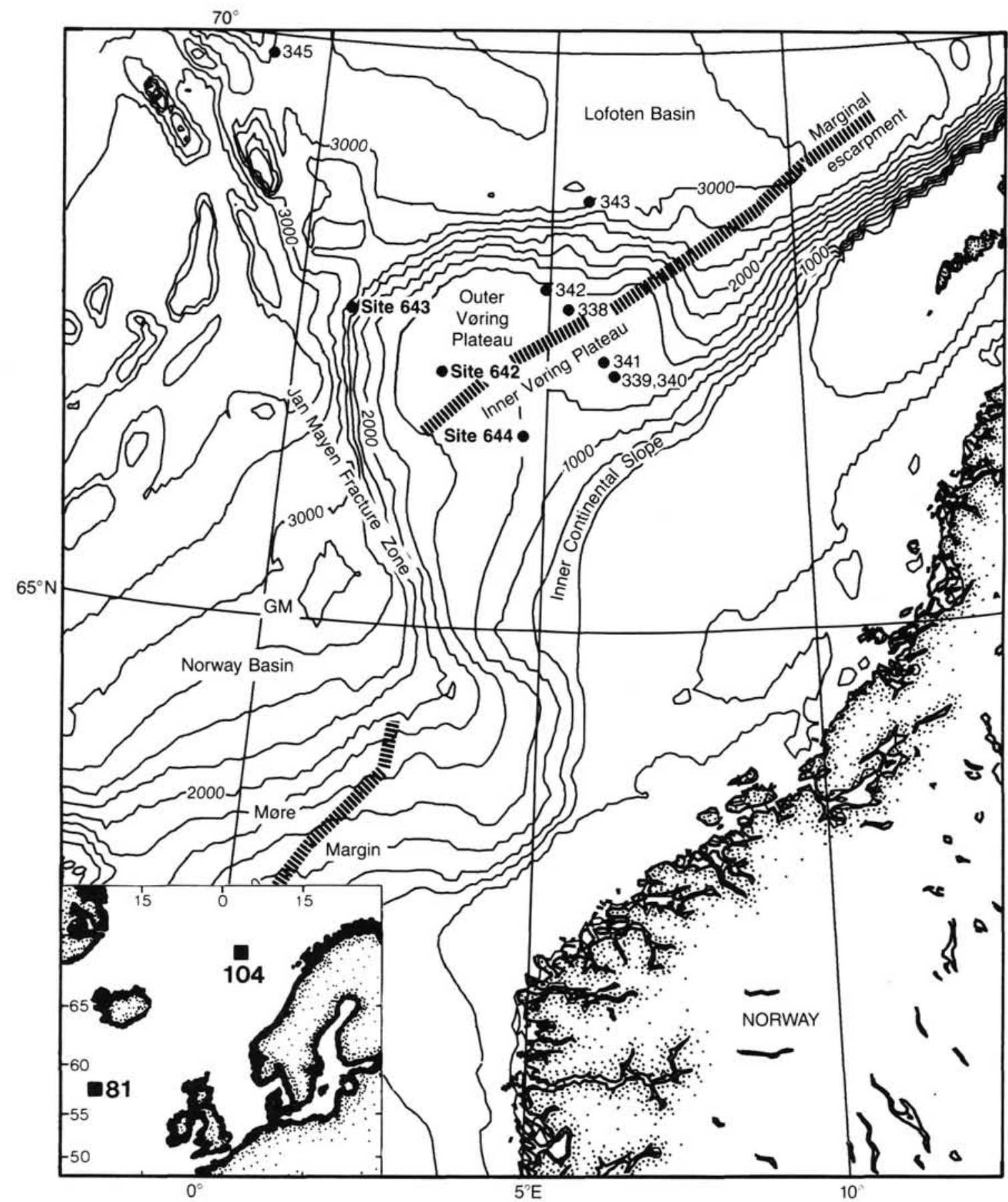

Figure 1. Location map of Vøring Plateau showing the ODP Leg $104(642,643,644)$ and DSDP Leg $38(338,339,340,341,342$, 343) drilling sites contours in meters. Inset: location of DSDP Leg 81 drilling sites at the SW margin of the Rockall Plateau, with respect to DSDP Leg 38 and ODP Leg 104 sites.

\section{STRATIGRAPHY AND LITHOLOGY OF TEPHRA HORIZONS}

Textures and mineralogy

Tephra at all sites occur as discrete or disseminated ash layers, lenses, or pods. Discrete ash layers often exhibit a sharp bottom and a gradational top. Some are normally graded. The colors, reflecting mainly the acidic to basic composition of glass shards, range from white or light gray to dark gray. Some layers are uniform in color, whereas others are color-zoned, always with a lighter colored base. Discrete and disseminated ash layers range in thickness from $<1$ to $10 \mathrm{~cm}$ (Fig. 2A). The thinnest $(<1 \mathrm{~cm})$ layers clearly predominate at Site 643 , unlike Site 642 where intermediate thicknesses $(1-7 \mathrm{~cm})$ are commonly observed. The thickest beds are usually of purely acidic composition while almost half of the thinnest ones are of bimodal (acidic/basic) compositions. In general, there is no correlation between the thicknesses of the ash layers and their stratigraphic position (Eldholm, Thiede, Taylor, et al., 1987).

All Leg 104 ash layers are free of lithics and are dominantly glassy. In most cases, the crystal fraction of tephra is less than $10 \%$ in volume, although it can occasionally reach up to $35 \%$. 

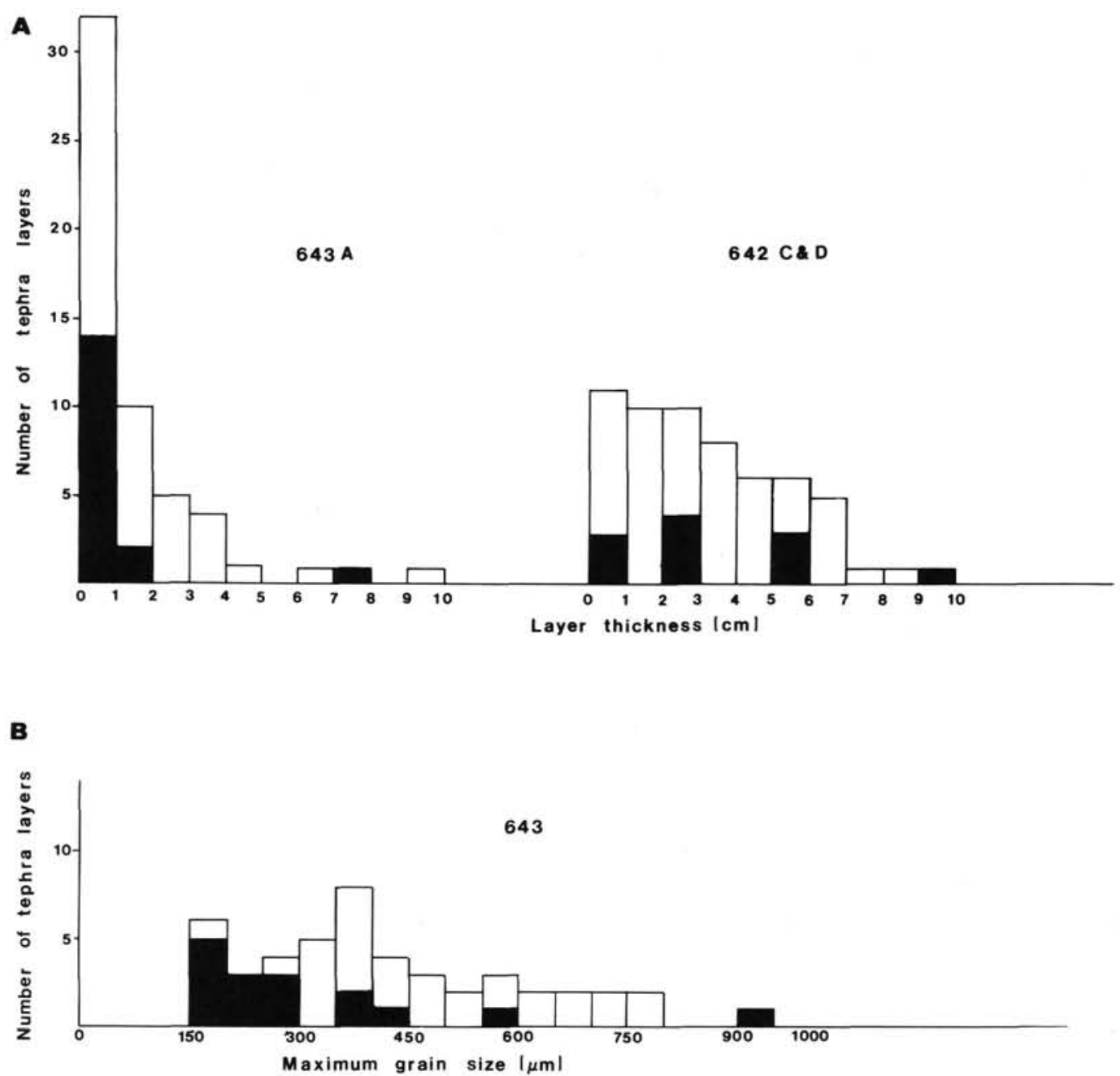

Figure 2. Frequency distribution of tephra layer thicknesses (A) and maximum grain sizes (B) in Sites 642 and 643. Unshaded areas: tephra layers of acidic composition (rhyolites to icelandites, A and B types). Shaded areas: bimodal acidic-basic layers (rhyolites to $\mathrm{Mg}$-rich basalts and ferrobasalts, $\mathrm{C}$ type).

Some crystals (quartz, feldspars of various compositions, usually orthoclase-rich) are of a terrigenous origin and are easily recognized on smear slides or under the Scanning Electron Microscope (SEM) by their well-rounded shapes. However, this detrital, nonvolcanic, part of the ash layers never exceeds $10 \%$ by volume. Most of the feldspar phenocrysts are pyroclastic in origin, as evidenced by numerous glass-feldspar composite grains. Some of the ash layers contain plagioclase which ranges in composition from bytownite to oligoclase (Tables 1 and 2; Fig. 3); others contain two feldspars, anorthoclase and sanidine or orthoclase and plagioclase. A few percent zircon, apatite, amphibole (hornblende), pyroxene (augite), and biotite occur in some cases. The glass shards are often coated and cemented with pyrite, giving a black color to the tephra. The alteration of glasses into clays is discussed later. However, with the exception of some completely glauconitized ash layers, the amount of in-situ altered glasses in Leg 104 ash layers is relatively low, fluctuating between 0 and $30 \%$ of the whole vitric material (Table 1).

Increasing vesicularity of glasses, resulting in the change of shard morphology from cuniform to cuspate and platy (Fischer and Schmincke, 1984), is correlated with change in color from brown to olivine green and colorless, and decreasing refractive index (Eldholm, Thiede, Taylor, et al., 1987). These petrographic criteria were applied on the ship to distinguish between three compositional tephra groups, listed as A, B, C and referred to as being of rhyolitic, icelanditic, and tholeiitic andesitic compositions, respectively (Table 1 ). The maximum grain size, measured on smear slides, is dependent on the shard morphology. The frequency curve of maximum grain size in discrete and disseminated ash layers at Site 643, shows maxima between 150 and $300 \mu \mathrm{m}$ for colored (i.e., basic) glasses and maxima between 300 and $400 \mu \mathrm{m}$ for colorless (i.e., acidic), glasses (Fig. 2B). With a single exception, the larger grains correspond to pumice shards. The medium grin size is less dependent on the glass composition and the maximum grain size does not change significantly between sites nor in different-age ash layers (Eldholm, Thiede, Taylor, et al., 1987). The average medium grain size measured on 45 selected ash layers from the three ODP Leg 104 sites is ca. $180 \mu \mathrm{m}$.

\section{Temporal variations}

Coring at Site 643 , located at the base of the Vøring Plateau (Fig. 1), recovered 55 ash layers within lithologic Units I (terrigenous muds), II, and III (biogenic, mostly diatom oozes) of Pleistocene to early Miocene age (Fig. 4) (Eldholm, Thiede, Taylor, et al., 1987). On the basis of petrographic criteria used on the ship for chemical classification of tephra, as well as chemical analyses presented hereafter, 38 ash layers are of acidic 


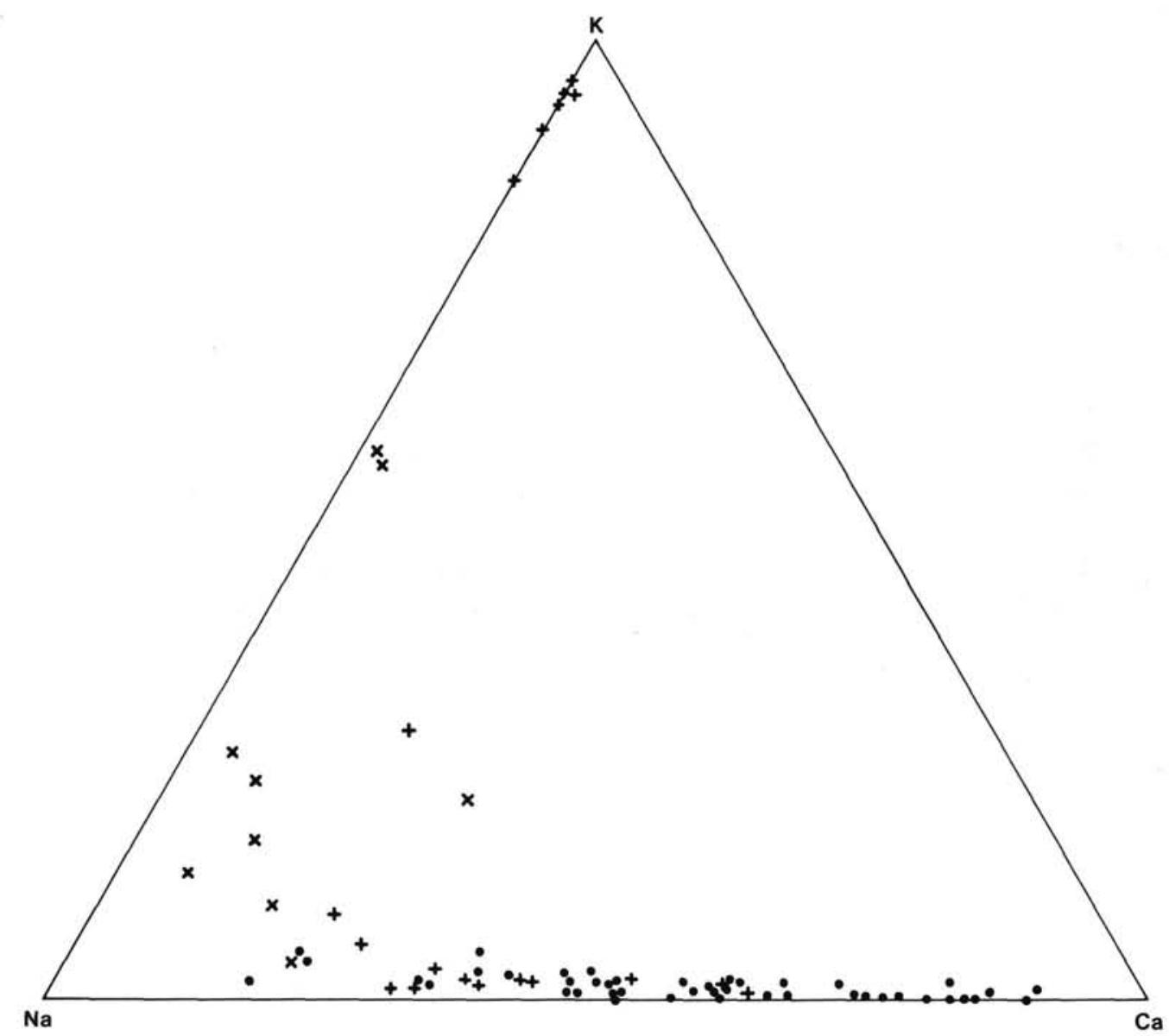

Figure 3. Compositions of feldspars from ash layers. $\bullet$ : ash layers containing plagioclase only; $\mathrm{X}$ : anorthoclase and sanidine-bearing ash layers; +: plagioclase and orthoclase-bearing ash layers.

composition (rhyolites to icelandites, A and B type) and 17 ash layers are of bimodal acidic-basic composition (rhyolites to $\mathrm{Mg}$ rich basalts and ferrobasalts, $\mathrm{C}$ type). From the three holes drilled at Site 642, located at the outer Vøring Plateau, 91 tephra horizons were identified. They represent (because of duplicate recovery in Holes 642B and 642C) 58 ash layers occurrences, 47 of which are listed as A and B type and 11 as C type. These tephra horizons are found in the equivalent lithostratigraphic units at Site 643 (Fig. 4); however, the two deepest recovered layers, possibly correlated with Leg 38 horizons (Sylvester, 1978), may be of Oligocene age. At Site 644, located at the inner part of the margin, the cored sedimentary sequence is limited to the Pliocene-Pleistocene and only three distinct ash layers, one of which is $C$ type, are present in the interbedded glacial-interglacial muds of Quaternary age.

Tentative correlations of layer horizons from site to site, using both the petrographic data and the biostratigraphic and paleomagnetic scales, are shown in Figure 4. It appears that 94 individual ash layers, 71 of which are of acidic composition, record the Neogene to Quaternary volcanic activity.

With the aim of interpreting the frequency of ash layer occurrence with time, we divided the recovered sedimentary sequences from the three sites into 1-Ma intervals. These intervals were defined on the basis of the Leg 104 biostratigraphic correlation chart (Eldholm, Thiede, Taylor, et al., 1987) which shows a large number of unconformities. The numbers of ash layers found per 1-m.y. interval, without a correction factor for the degree of core recovery ( 80 to $95 \%$ ), are shown in Figure 5 histo- grams. The apparent peaks of volcanic activity (Fig. 5A) are mainly due to increases of acidic ash layer frequency; the basic layer frequency remains more or less constant throughout the cored sedimentary sequences (Fig. 5A).

On the whole, ash layer frequencies seem to decrease at Site 642 as well as at Site 643 from the Miocene to the Pliocene and Pleistocene. However, a compilation of the three site histograms (Fig. 5B) indicates two apparent maxima of volcanic activity; an early one at the early-middle Miocene boundary (16 to $14 \mathrm{Ma}$ ) and another during the late Miocene ( 8 to $7 \mathrm{Ma}$ ). These two peaks are separated by a large sedimentary hiatus of $3 \mathrm{Ma} \mathrm{(13}$ to $10 \mathrm{Ma}$ ). Our results are thus in disagreement with the estimates of Donn and Ninkovich (1980), who have proposed an increase of explosive volcanism in the North Atlantic during Pliocene, as well as with the proposal by Kennett and Thunell (1975) of a global increase of Quaternary volcanism. An early to middle Miocene volcanic peak was previously reported in the North Atlantic (Sigurdsson and Loebner, 1981) as well as on a global scale (Kennett and Thunell, 1975). The late Miocene peak was previously unknown, especially because of the poor recovery from the DSDP Leg 38.

\section{ANALYTICAL PROCEDURES}

All the analyses were performed on the tephra horizon ash fraction $>35-63 \mu \mathrm{m}$, separated by sieving and cleaned by ultrasonic methods. Smear-slide observations of this fraction suggest it is the most representative of the compositional variations within an ash layer. Furthermore, this grain size is better suited for SEM and microprobe analyses. 
Table 1. Composition of Leg 104 tephra horizon samples.

\begin{tabular}{|c|c|c|c|c|c|c|c|c|c|c|c|c|c|c|c|c|}
\hline \multirow[b]{2}{*}{ Hole } & \multirow[b]{2}{*}{ Core } & \multirow{2}{*}{$\begin{array}{c}\text { Interval } \\
(\mathrm{cm})\end{array}$} & \multirow{2}{*}{$\begin{array}{l}\text { Tephra } \\
\text { type }^{\text {a }}\end{array}$} & \multicolumn{6}{|c|}{ Fresh glass ${ }^{b}$} & \multicolumn{2}{|c|}{$\begin{array}{l}\text { Altered } \\
\text { glass }^{\mathrm{c}}\end{array}$} & \multicolumn{4}{|c|}{ Associated minerals ${ }^{d}$} & \multirow[b]{2}{*}{ Age } \\
\hline & & & & Rhy. & Ic. & Th-An. & Fe-Bas. & 1.Mg-Th. & Th. & Rhy. & Bas. & Plagio. & K-Feld. & Mafic. & Terr. & \\
\hline \multirow[t]{16}{*}{$643 \mathrm{~A}$} & $2-3$ & $74-75$ & $\mathrm{~B} / \mathrm{C}$ & 90 & & & 10 & & & & & + & & & ++ & Pleist. \\
\hline & $6-3$ & $24-25$ & A & 100 & & & & & & & & + & & & & \\
\hline & $8-3$ & $125-126$ & $\mathrm{~B} / \mathrm{A}$ & 95 & 5 & & & & & & & & + & & + & Plio. \\
\hline & $11-1$ & $104-105$ & A & 100 & & & & & & & & & ++ & & & Late \\
\hline & $11-2$ & $76-77$ & B & 90 & 10 & & & & & + & & + & & & ++ & Mio. \\
\hline & $11-5$ & $8-9$ & A & 100 & & & & & & & & & & & + & Middle \\
\hline & $11-7$ & $9-10$ & $\mathrm{~A} / \mathrm{B}$ & 100 & & & & & & & & & & & & Mio. \\
\hline & $15-4$ & $144-145$ & B & 90 & 10 & & & & & & & & & & & \\
\hline & $16-6$ & $48-49$ & $\mathrm{~B} / \mathrm{A}$ & 95 & & & & 5 & & + & & & & & ++ & \\
\hline & $19-1$ & $48-49$ & $\mathrm{~B} / \mathrm{C}$ & 15 & 40 & & 15 & 30 & & ++ & ++ & ++ & & & + & \\
\hline & $19-3$ & $94-95$ & A & 100 & & & & & & & & & & & & \\
\hline & $22-3$ & $110-112$ & C & 10 & & & 40 & 50 & & +++ & + & & + & & & Early \\
\hline & $25 \mathrm{CC}$ & $11-12$ & C & 15 & & & & 45 & 40 & & & & & & & Mio. \\
\hline & $26-4$ & $118-119$ & C & 20 & 10 & & 20 & 50 & & & & & & & & \\
\hline & $28-1$ & $67-68$ & C & 30 & 10 & & & 40 & 20 & & & + & & & + & \\
\hline & $28-2$ & $149-150$ & C & 70 & 20 & 5 & & & 5 & +++ & & ++ & & & & \\
\hline \multirow[t]{9}{*}{$642 B$} & $6-1$ & $131-132$ & B & 100 & & & & & & & & & & & & Pleist. \\
\hline & $9-3$ & $95-96$ & $\mathrm{C}$ & 40 & 5 & 15 & 25 & 10 & 5 & & & & & & & Plio. \\
\hline & $12-5$ & $84-86$ & B & 75 & 25 & & & & & & + & & & & & \\
\hline & $13 \mathrm{CC}$ & $11-12$ & A & 100 & & & & & & & & ++ & + & & & \\
\hline & $16-2$ & $27-29$ & C & 70 & & 10 & 15 & 5 & & & & + & & & & Late \\
\hline & $16-2$ & $110-112$ & C & 50 & 5 & & 25 & 20 & & + & + & + & & & & Mio. \\
\hline & $19-2$ & $76-78$ & B & 60 & 5 & 30 & 5 & & & & & & & & & \\
\hline & $20-5$ & $112-113$ & A & 95 & & & & 5 & & & & + & + & & & Middle \\
\hline & $21-2$ & $136-137$ & & 85 & 5 & 10 & & & & & & & + & & & Mio. \\
\hline \multirow[t]{8}{*}{$642 \mathrm{C}$} & $7-1$ & $133-135$ & A & 95 & & 5 & & & & + & + & ++ & ++ & & ++ & Plio. \\
\hline & $12-2$ & $30-31$ & A & 100 & & & & & & + & & & & & & Late \\
\hline & $15-4$ & $87-88$ & B & 80 & 10 & 10 & & & & & & & & & & Late \\
\hline & $15-6$ & $81-82$ & B & 65 & & 20 & 15 & & & & + & ++ & + & & & \\
\hline & $18-3$ & $21-22$ & A & 100 & & & & & & & & ++ & + & & & \\
\hline & $19-3$ & $71-74$ & B & 60 & 5 & 15 & 20 & & & & & ++ & & & & Middle \\
\hline & $21-6$ & $4-7$ & $\mathrm{C}$ & & 10 & 35 & 35 & 35 & 20 & + & ++ & + & & & & Mio. \\
\hline & $24-3$ & $7-8$ & A & 80 & & 15 & 5 & & & & & + & & & & Early \\
\hline \multirow[t]{7}{*}{$642 \mathrm{D}$} & $6-2$ & $5-6$ & A & 80 & & 15 & 5 & & & & & & & & + & \\
\hline & $7-2$ & $132-133$ & C & 25 & 10 & 5 & 10 & 50 & & & ++ & & & & & Early \\
\hline & $7-6$ & $70-71$ & C & 5 & 5 & 20 & 25 & 35 & 10 & ++ & ++ & & & + & & Mio. \\
\hline & $8-1$ & $119-120$ & C & 50 & & & & 25 & 25 & +++ & +++ & & & & & \\
\hline & $8-4$ & $23-24$ & B & 85 & 5 & 10 & & & & & & . & & & & \\
\hline & $11-1$ & $82-83$ & B & 70 & & 15 & 15 & & & + & & + & & & + & $\begin{array}{l}\text { Early } \\
\text { Mio. }\end{array}$ \\
\hline & $11-1$ & $92-93$ & B & 70 & 15 & 15 & & & & & & + & & & & \\
\hline \multirow[t]{4}{*}{$644 \mathrm{~A}$} & $4-1$ & $131-132$ & & 60 & & 20 & 20 & & & & & & & & & \\
\hline & $11-2$ & $41-42$ & & 100 & & & & & & & & & & & & \\
\hline & $11-5$ & $77-78$ & & 100 & & & & & & & & & & & & Pleist. \\
\hline & $4-3$ & $32-36$ & & 75 & 5 & 15 & 5 & & & & + & + & + & + & ++ & \\
\hline 644B & $11-3$ & $36-37$ & & 100 & & & & & & & & & + & & + & \\
\hline
\end{tabular}

a Type of compositional group of glasses according to criteria defined by Leg 104 Shipboard Scientific Party (see text and Eldholm, Thiede, Taylor, et al., 1987)

b Compositional groups based on chemical analyses using a nomenclature based on MgO contents (Flower et al., 1982; see text). Note the good agreement between A and Rhyolite, B and Rhyolite to Ferrobasalt, $\mathrm{C}$ and Rhyolite to Tholeiite.

c, d Relative amounts referred as $+:$ present; $++:$ frequent; $+++:$ abundant, of altered glasses of rhyolitic and basaltic composition and associated minerals (mafic: Hornblende and Augite; Terr.: detrital quartz and feldspars).

Major- and trace-element compositions of the bulk separated fraction of volcanic glasses were determined either by atomic absorption analyses (major elements and $\mathrm{Li}, \mathrm{Rb}, \mathrm{Sr}, \mathrm{Ba}, \mathrm{V}, \mathrm{Cr}, \mathrm{Co}, \mathrm{Ni}, \mathrm{Cu}, \mathrm{Zn}$ ) or by instrumental neutron activation (Jaffrezic et al., 1977) for REE and other hygromagmaphile elements.

Individual major-element composition of single glass shard separates included in epoxy resin and polished, was determined either by electron microprobe (EM) or by scanning electron microprobe fitted with an energy-dispersive spectrometer (SEM/EDS). Each technique has advantages and disadvantages. For the EM work, the major problem is the loss of alkalis under beam, especially Na. Rather than recalculation procedures taking account of the rate of alkali loss (Nielsen and Sigurdsson, 1981), we used a large microprobe beam diameter (20 $\mu \mathrm{m})$ and short counting time (6 s). The EM used was a Camebax-type automated microprobe with Microbeam system, working under $15 \mathrm{kV}$ and $10 \mathrm{nA}$. Under these conditions and $6 \mathrm{~s}$ counting time, the detection limit is ca. $0.3 \%$ with analytical precisions better than $5 \%$. The lack of important alkali loss was checked by C.I.P.W. norm calculation on the glass analyses (lack or scarcity of normative corundum). For SEM/EDS studies, large scanning areas $\left(100 \mu \mathrm{m}^{2}\right)$ were analysed under $15 \mathrm{kV}$ with real-time acquisition of $120 \mathrm{~s}$. Under these conditions, no significant loss of alkalis was observed; however, the analytical precisions are less good than the EM ones. The relative errors are less than 3\% for elements with concentrations between 5 and $10 \%$, and $20 \%$ for elemental concentrations $<5 \%$. The detection limit is $0.1 \%$ The weight deficit to 100 is often unreliable to the water content. Results obtained by the two techniques were recalculated to 100 percent (oxide values in percent by weight, water-free basis) to allow for comparison.

\section{MAJOR-ELEMENT COMPOSITION OF INDIVIDUAL GLASS PARTICLES}

\section{General Features and Classification}

The prominent feature of the ash horizons studied is their chemical heterogeneity. Out of the 45 examples listed in Table 1, only 12 are chemically homogeneous, and typically rhyolitic. Twenty-four other layers range in composition from rhyolite to more basic types, but with a dominant rhyolitic component $(>50 \%)$. Only nine are predominantly basic or intermediate, 
Table 2. Microprobe analyses of feldspars from Leg 104 ash layers. 1 to 5: plagioclases; 6 to 8: anorthoclase; 9: soda sanidine; 10 to 12: orthoclase. $\mathrm{Fe}_{2} \mathrm{O}_{3}{ }^{*}$ : total iron as $\mathrm{Fe}_{2} \mathrm{O}_{3}$. Na, K, Ca: atomic numbers recalculated to 100 .

\begin{tabular}{lrrrrrrrrrrrr}
\hline Anal. No. & 1 & 2 & 3 & 4 & 5 & 6 & 7 & 8 & 9 & 10 & 11 \\
\hline $\mathrm{Hole}$ & $642 \mathrm{C}$ & $642 \mathrm{C}$ & $642 \mathrm{C}$ & $642 \mathrm{~B}$ & $642 \mathrm{D}$ & $644 \mathrm{~B}$ & $643 \mathrm{~A}$ & $642 \mathrm{~B}$ & $644 \mathrm{~B}$ & $642 \mathrm{C}$ & $642 \mathrm{C}$ & $642 \mathrm{~B}$ \\
$\mathrm{Core}$ & $24-3$ & $18-3$ & $15-6$ & $16-2$ & $11-1$ & $11-3$ & $8-3$ & $20-5$ & $11-3$ & $18-3$ & $15-6$ & $13 \mathrm{CC}$ \\
Interval $(\mathrm{cm})$ & $7-8$ & $21-22$ & $80-82$ & $27-29$ & $92-93$ & $36-37$ & $125-126$ & $112-113$ & $36-37$ & $21-22$ & $80-82$ & $11-12$ \\
\hline $\mathrm{SiO}_{2}$ & 63.20 & 53.87 & 55.43 & 52.64 & 49.03 & 64.84 & 66.40 & 67.42 & 66.43 & 64.41 & 64.58 & 65.45 \\
$\mathrm{Al}_{2} \mathrm{O}_{3}$ & 23.07 & 25.19 & 27.16 & 28.60 & 31.92 & 21.00 & 19.87 & 19.68 & 18.33 & 18.49 & 18.77 & 18.92 \\
$\mathrm{Fe}_{2} \mathrm{O}_{3}{ }^{*}$ & 0.34 & 0.48 & 0.83 & 0.76 & 0.38 & 0.18 & 0.19 & 0.53 & 0.13 & - & 0.06 & - \\
$\mathrm{CaO}^{\mathrm{Na}}{ }_{2} \mathrm{O}$ & 4.52 & 7.38 & 9.96 & 12.67 & 15.32 & 3.41 & 2.19 & 0.86 & 0.35 & - & - & 0.01 \\
$\mathrm{~K}_{2} \mathrm{O}$ & 8.33 & 7.49 & 6.07 & 4.50 & 2.52 & 8.52 & 8.02 & 8.31 & 4.67 & 1.19 & 0.77 & 0.57 \\
$\mathrm{TOTAL}$ & 0.68 & 0.51 & 0.22 & 0.07 & 0.03 & 1.66 & 2.94 & 4.61 & 9.69 & 16.10 & 15.28 & 15.83 \\
\hline $\mathrm{Na}$ & 100.14 & 99.42 & 99.67 & 99.24 & 99.20 & 99.61 & 99.61 & 101.41 & 99.60 & 100.19 & 99.46 & 100.78 \\
$\mathrm{~K}$ & 73.87 & 62.91 & 51.82 & 38.97 & 22.88 & 74.10 & 71.90 & 70.31 & 41.50 & 10.09 & 7.08 & 5.21 \\
$\mathrm{Ca}$ & 3.96 & 2.84 & 1.23 & 0.39 & 0.15 & 9.50 & 17.30 & 25.67 & 56.70 & 89.91 & 92.92 & 94.74 \\
& 22.17 & 34.25 & 46.95 & 60.63 & 76.97 & 16.40 & 10.80 & 4.02 & 1.80 & - & - & 0.05 \\
\hline
\end{tabular}

but a minor rhyolitic component was identified in all but one case (Table 1). Such chemical heterogeneities were previously described in North Atlantic deep-sea tephra by Sigurdsson and Loebner (1981) and are attributed to mixed magma eruptions, the most likely source of which is Iceland.

Typical analyses of individual fresh glass shards from two heterogeneous ash layers are shown in Table 3 . Analyses 1 to 10 were obtained by SEM/EDS, analyses 11 to 20 by microprobe, using a defocused beam $20 \mu \mathrm{m}$ in diameter. The lack, or small amounts, of normative corundum suggest that alkalis were not greatly underestimated, as would be the case using a focused beam for microprobe analysis. The analytical totals of microprobe analyses range from ca. $96 \%$ to ca. $99 \%$; their differences from $100 \%$ fall within the range of the loss on ignition values (ca. 1.5 to ca. $5 \%$ ) found for bulk analyses of ash layers (Table 8); thus these differences are attributed mainly to the water contents of the glasses. The analytical totals of SEM/EDS analyses are usually lower (ca. 88-92\%) and are not directly related to the water contents. The diagrams shown hereafter were made using analyses obtained by the two techniques and recalculated to $100 \%$ by weight (water-free basis).

Analyses indicate the tephras range in composition from basalts to rhyolites (Table 3). Major-element features (silica-saturation or oversaturation, increase of $\mathrm{TiO}_{2}$ and total iron from basalts to intermediate compositions, high $\mathrm{FeO}^{*} / \mathrm{MgO}$ ratios, low $\mathrm{K}_{2} \mathrm{O}$ contents) are typical of tholeitic series. Thus, the chemical nomenclature of glass shard compositions is based on tholeiitic magma series classifications. Chemical criteria used for these classifications include $\mathrm{MgO}, \mathrm{TiO}_{2}, \mathrm{SiO}_{2}, \mathrm{~K}_{2} \mathrm{O}$ contents; $\mathrm{FeO} *$ / $\mathrm{FeO}^{*}+\mathrm{MgO}$ ratios; Differentiation Index; and Solidification Index (see Wood, 1978; Flower et al., 1982; Sigurdsson and Loebner, 1981). We used $\mathrm{MgO}$ content for classification to minimize aberrations arising from the recalculation of analyses with low analytical weight sums to $100 \%$, underestimates of alkali contents, or $\mathrm{K}_{2} \mathrm{O}$ variations linked to alteration processes (see below). The classification scheme used, adapted from Flower et al., 1982, is as follows: high-Mg tholeiitic basalt: $\mathrm{MgO}>6.5$ weight $\%$; low-Mg tholeiitic basalt: $\mathrm{MgO}=6.5-5.0 \%$; ferrobasalt: $\mathrm{MgO}=5.0-4.0 \%$; tholeiitic andesite: $\mathrm{MgO}=4.0-2.0 \%$; icelandite: $\mathrm{MgO}=2.0-0.5 \%$; rhyolite: $\mathrm{MgO}<0.5$ weight $\%$. Estimates of the relative abundances of these compositional groups in the 45 tephra horizons studied are given in Table 1.

\section{Chemical Variations Resulting From Alteration of the Glasses}

SEM/EDS investigations reveal variable degrees of volcanic glass alteration. $\mathrm{MgO}$ contents of glass-shard separates from two ash layers are plotted vs. other major-elements concentra- tions in Figure 6. The chemical trends shown on the first diagram (Fig. 6A) are those of "fresh" glasses which exhibit an increase in alkalis with increased degree of differentiation (decreasing $\mathrm{MgO}$ contents). By contrast, the trends on the second diagram (Fig. 6B) show different patterns due to the presence of hydrated glasses originally of rhyolitic composition. This alteration is illustrated by a relative enrichment in $\mathrm{Al}_{2} \mathrm{O}_{3}$ and depletion in $\mathrm{SiO}_{2}$ and $\mathrm{K}_{2} \mathrm{O}$. The Fe- and Ti-enrichment trends in ferrobasalt and low-MgO tholeiite groups are well preserved. This example shows that the alteration of volcanic glasses may be selective, i.e., dependent on their chemical composition. It is important to distinguish the alterations of silicic glasses (rhyolites to icelandites in this study) from those of more basic glasses (tholeiitic andesites to tholeiites).

\section{Alteration to smectites}

This process occurs irregularly in the ash layers of early Miocene to Pleistocene age (Table 1). Its successive stages can be distinguished by chemical changes leading to altered and highly altered glasses.

In the case of silicic glasses, the initial alteration stage is characterized by a selective dissolution resulting in a loss of $\mathrm{K}$, $\mathrm{Na}$, and $\mathrm{Si}$, and relative gain of $\mathrm{Fe}$. The advanced stage is the complete dissolution of glass, passive accumulation of $\mathrm{Fe}$, and precipitation of secondary phases, with absolute gain of Mg. The final alteration product is a smectite of iron-beidellite type (Tables 4 and 5).

For basic glasses, the initial alteration stage is marked by a loss of $\mathrm{Si}, \mathrm{Mg}$, and $\mathrm{Fe}$, and a relative gain of $\mathrm{Al}$ with minor changes in $\mathrm{Na}$ and $\mathrm{Ca}$. Passive accumulation of iron reflects increasing alteration; the crystalline phase is an iron-beidellite, always associated with secondary calcite.

These two alteration trends are related to the chemical composition of glasses rather than to a change in percolating solutions: only the iron-smectite phase remains in equilibrium under local conditions of Leg 104 rocks. Numerous aspects of the alteration of basaltic glasses are those associated with palagonitization (Staudigel and Hart, 1983). The rate of palagonite formation appears to be lower than that of the smectite genesis on the surface of silicic glasses; the evolution of palagonite into crystalline phases may have been inhibited by the precipitation of secondary calcite. Occurrence of secondary calcite could explain the frequent coexistence in ash layers of deeply altered glasses together with fresh basic glasses.

\section{Alteration to Glauconite}

This process occurs chiefly in lower Miocene ash layers. The altered grains are well-rounded, green, and display all the steps 


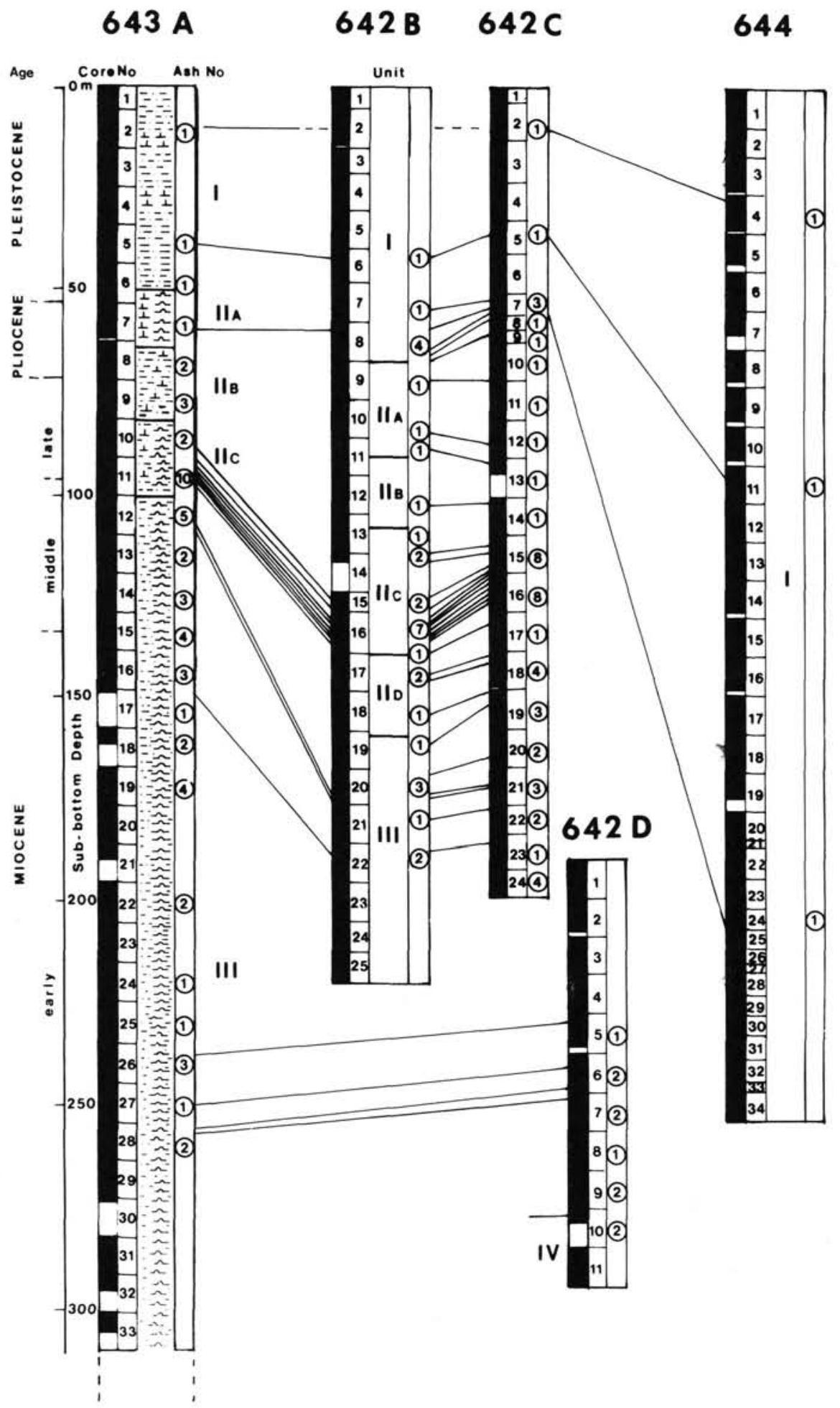

Figure 4. Stratigraphic distribution of ash layers from sedimentary sequences drilled on the Vøring Plateau. Lines show tentative correlations based both on petrographic criteria and chemical compositions of the tephra layers. I to IV: lithologic units (Eldholm, Thiede, Taylor, et al., 1987). Circled numbers show the number of ash layers recovered from each core. 


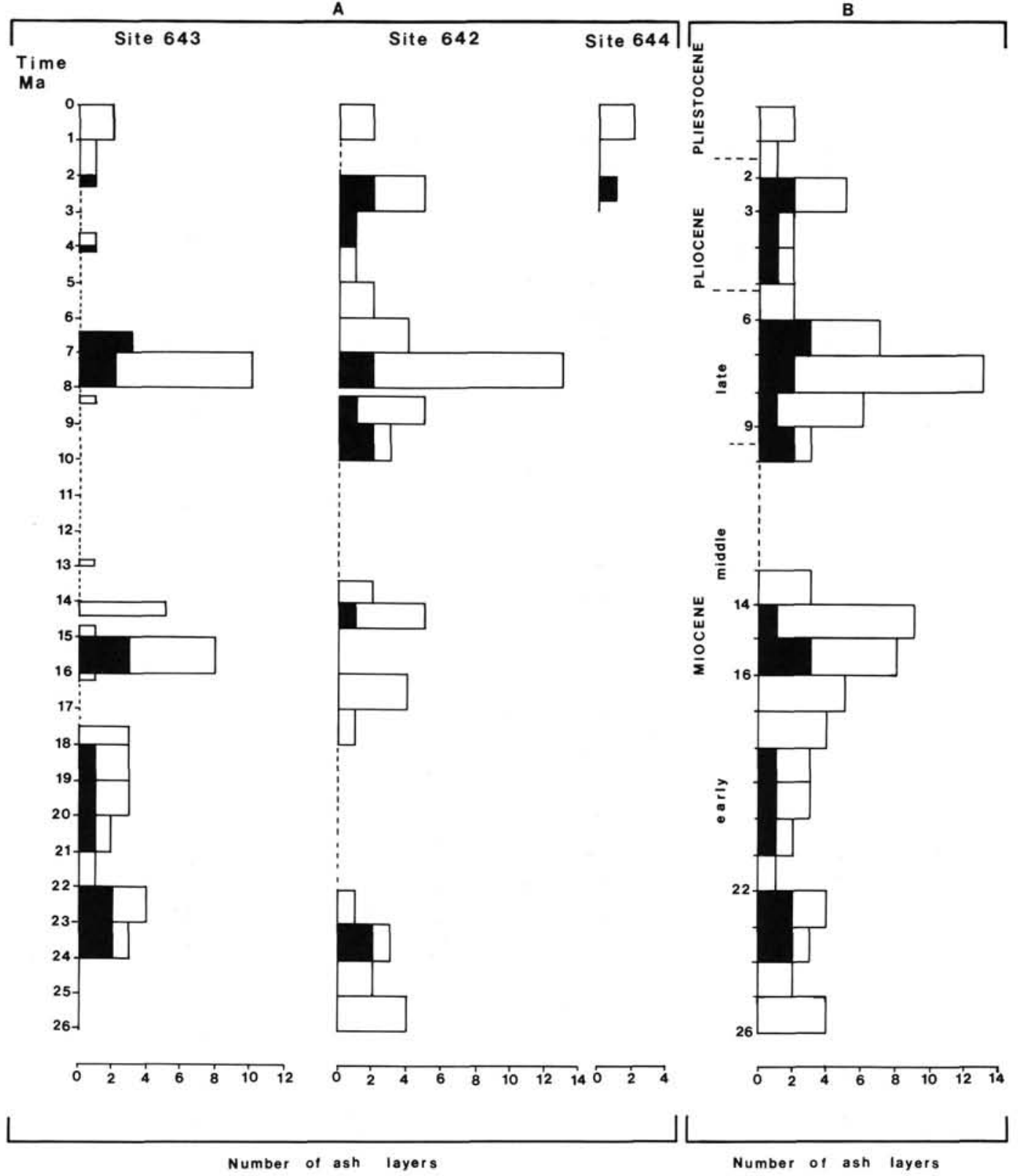

Figure 5. Time-related frequencies (per m.y. intervals) of ash layers in ODP Leg 104 sedimentary sequences. A. Numbers of ash layers per m.y. in ODP Leg 104 Sites 643, 642, and 644. Dashed lines indicate hiatuses (calibrated from the stratigraphic correlation chart of Eldholm, Thiede, Taylor, et al., 1987). B. Compilation of the data from the three sites. Shaded areas: bimodal layers; unshaded areas: acidic layers.

of glauconite replacement in both rhyolitic and basaltic glass. In the case of Si-rich glasses, the first step consists of development of iron-rich smectites having the same chemical composition as those previously described from the highly altered glass. A second step is the progressive substitution of octahedral Al by Fe in smectite, possibly by successive processes of dissolution-recrystallization, accompanied by incorporation of $\mathrm{K}$ in the interlayer sites. For basaltic glasses, the same chemical trend is observed and the glauconite shows the same composition as above.

\section{Primary Composition Variations}

\section{Homogeneous and heterogeneous ash layers}

Table 1 and Figure 6 data show that the heterogeneous ash horizons display several patterns of distribution of the chemical groups defined above. For instance, Sample 104-642D-7X-06, $70-71 \mathrm{~cm}$ (Fig. 6B) contains glass shards ranging in composition from high-Mg tholeiites to rhyolites without a significant gap in the chemical trends (although the intermediate compositions are less common than the basaltic and rhyolitic/icelanditic ones). In contrast, Sample 104-643A-28X-01, 67-68 cm (Fig. 6A) is truly bimodal with $\mathrm{Mg}$-rich basaltic and rhyolitic shards, and with only two cases of intermediate compositions. The general distributions of the glass shard chemical composition are shown on the $\mathrm{TiO}_{2}$ and $\mathrm{FeO}^{*}$ vs. $\mathrm{MgO}$ diagrams of Figure 7.

\section{Homogeneous or subhomogeneous ash layers}

These layers are exemplified in Figure 7A. They can be exclusively rhyolitic (black points) or predominantly rhyolitic but extending toward icelanditic compositions (crosses). 
Table 3. Representive individual analyses (and corresponding normative parameters) of glass shards from two Leg 104 ash layers. Analyses 1 to 10 were obtained by SEM/EDS in Orsay and analyses 11 to 20 by Camebax-type microprobe analysis in Brest (with a $20-\mu \mathrm{m}$ beam diameter). FeO*: total iron as FeO. C.I.P.W. norms calculated with $15 \%$ total iron as $\mathrm{Fe}_{2} \mathrm{O}_{3}$ and $85 \%$ as $\mathrm{FeO}$.

\begin{tabular}{|c|c|c|c|c|c|c|c|c|c|c|}
\hline \multirow{2}{*}{$\begin{array}{l}\text { Sample } \\
\text { Analysis }\end{array}$} & \multicolumn{10}{|c|}{$104-643 \mathrm{~A}-19-1,48-49 \mathrm{~cm}$} \\
\hline & 1 & 2 & 3 & 4 & 5 & 6 & 7 & 8 & 9 & 10 \\
\hline $\mathrm{SiO}_{2}$ & 46.28 & 46.77 & 45.27 & 45.84 & 48.11 & 44.39 & 59.38 & 59.27 & 66.74 & 68.28 \\
\hline $\mathrm{TiO}_{2}$ & 2.25 & 2.18 & 2.19 & 2.42 & 2.56 & 2.34 & 1.43 & 1.18 & 0.62 & 0.45 \\
\hline $\mathrm{Al}_{2} \mathrm{O}_{3}$ & 11.47 & 11.74 & 11.21 & 11.26 & 11.93 & 19.65 & 11.94 & 11.60 & 10.55 & 10.24 \\
\hline $\mathrm{FeO}^{*}$ & 12.76 & 13.38 & 12.85 & 12.33 & 15.66 & 16.03 & 8.83 & 6.12 & 3.95 & 3.28 \\
\hline $\mathrm{MnO}$ & 0.21 & 0.27 & 0.37 & 0.38 & 0.26 & 0.28 & 0.07 & 0.03 & 0.15 & 0.00 \\
\hline $\mathrm{MgO}$ & 5.91 & 5.80 & 5.69 & 5.31 & 4.09 & 3.63 & 1.71 & 1.63 & 0.77 & 0.41 \\
\hline $\mathrm{CaO}$ & 10.68 & 10.67 & 10.26 & 9.50 & 9.67 & 9.01 & 4.63 & 4.21 & 2.32 & 1.65 \\
\hline $\mathrm{Na}_{2} \mathrm{O}$ & 2.01 & 2.80 & 2.44 & 2.25 & 2.48 & 1.74 & 3.53 & 3.09 & 2.10 & 2.34 \\
\hline $\mathrm{K}_{2} \mathrm{O}$ & 0.32 & 0.34 & 0.28 & 0.23 & 0.47 & 0.42 & 1.34 & 1.45 & 1.89 & 2.19 \\
\hline TÖTAL & 91.89 & 93.95 & 90.56 & 89.52 & 95.23 & 88.49 & 92.86 & 88.58 & 89.09 & 88.84 \\
\hline Q & 1.92 & & & 3.34 & 2.80 & 4.99 & 20.17 & 25.71 & 43.70 & 45.41 \\
\hline Or & 2.05 & 2.13 & 1.82 & 1.51 & 2.91 & 2.80 & 8.51 & 9.66 & 12.52 & 14.56 \\
\hline $\mathrm{Ab}$ & 18.46 & 25.15 & 22.73 & 21.21 & 21.96 & 16.58 & 32.10 & 29.47 & 19.92 & 22.26 \\
\hline An & 23.16 & 19.61 & 20.72 & 22.23 & 20.98 & 22.54 & 13.74 & 15.23 & 12.91 & 9.21 \\
\hline Co & & & & & & & & & 0.94 & 1.15 \\
\hline OI & & 6.36 & 1.56 & & & & & & & \\
\hline D.I. & 22.43 & 27.28 & 24.56 & 26.06 & 27.68 & 24.36 & 60.78 & 64.84 & 76.15 & 82.23 \\
\hline S.I. & 27.86 & 25.68 & 26.31 & 25.90 & 17.81 & 16.43 & 11.05 & 13.23 & 8.69 & 4.99 \\
\hline
\end{tabular}

\begin{tabular}{|c|c|c|c|c|c|c|c|c|c|c|}
\hline \multirow{2}{*}{$\begin{array}{l}\text { Sample } \\
\text { Analysis }\end{array}$} & \multicolumn{10}{|c|}{$104-642 \mathrm{C}-21-06,4-7 \mathrm{~cm}$} \\
\hline & 11 & 12 & 13 & 14 & 15 & 16 & 17 & 18 & 19 & 20 \\
\hline $\mathrm{SiO}_{2}$ & 48.98 & 49.55 & 49.72 & 49.89 & 50.18 & 54.87 & 61.97 & 66.60 & 65.72 & 69.54 \\
\hline $\mathrm{TiO}_{2}$ & 3.02 & 3.28 & 3.34 & 3.54 & 3.26 & 2.49 & 4.04 & 4.14 & 2.47 & 0.24 \\
\hline $\mathrm{Al}_{2} \mathrm{O}_{3}$ & 13.77 & 13.49 & 13.16 & 13.12 & 12.75 & 14.00 & 17.12 & 13.12 & 13.90 & 12.78 \\
\hline $\mathrm{FeO}^{*}$ & 13.08 & 12.94 & 13.19 & 13.97 & 13.09 & 10.31 & 3.93 & 4.02 & 4.01 & 3.62 \\
\hline $\mathrm{MnO}$ & 0.17 & 0.24 & 0.16 & 0.23 & 0.17 & 0.01 & 0.04 & 0.28 & 0.15 & 0.02 \\
\hline $\mathrm{MgO}$ & 5.22 & 4.99 & 4.65 & 4.37 & 4.18 & 2.91 & 1.40 & 0.27 & 0.22 & 0.03 \\
\hline $\mathrm{CaO}$ & 8.86 & 8.85 & 8.89 & 8.21 & 8.31 & 7.26 & 4.23 & 1.64 & 2.26 & 0.84 \\
\hline $\mathrm{Na}_{2} \mathrm{O}$ & 3.31 & 3.32 & 2.80 & 3.40 & 3.25 & 4.51 & 3.96 & 4.25 & 4.18 & 5.45 \\
\hline $\mathrm{K}_{2} \mathrm{O}$ & 0.77 & 0.79 & 0.91 & 0.94 & 0.97 & 1.31 & 2.44 & 3.01 & 2.87 & 3.49 \\
\hline TÖTAL & 97.18 & 97.45 & 96.82 & 97.67 & 96.16 & 97.67 & 99.13 & 97.33 & 95.78 & 96.01 \\
\hline Q & & & 2.97 & 0.82 & 2.63 & 3.75 & 18.83 & 27.23 & 25.58 & 22.23 \\
\hline Or & 4.67 & 4.78 & 5.54 & 5.67 & 5.95 & 7.91 & 14.53 & 18.26 & 17.69 & 21.46 \\
\hline $\mathrm{Ab}$ & 28.74 & 28.75 & 24.40 & 29.37 & 28.52 & 38.99 & 33.76 & 36.90 & 36.88 & 47.98 \\
\hline An & 20.99 & 20.05 & 21.29 & 18.15 & 17.99 & 14.41 & 20.17 & 8.05 & 11.16 & 0.12 \\
\hline Co & & & & & & & 0.64 & & & \\
\hline 01 & 3.57 & 0.09 & & & & & & & & \\
\hline D.I. & 33.41 & 33.53 & 32.91 & 35.87 & 37.09 & 50.65 & 67.13 & 82.40 & 80.15 & 91.67 \\
\hline S.I. & 23.15 & 22.40 & 21.42 & 19.07 & 19.30 & 15.28 & 11.89 & 2.28 & 1.92 & 0.24 \\
\hline
\end{tabular}

\section{Heterogeneous (acidic/intermediate) layers}

These layers (Fig. 7B) are predominantly rhyolitic but also show an intermediate (andesitic to icelanditic) component separated by a significant chemical gap from the rhyolites.

\section{Heterogeneous (acidic/basic) layers}

These layers (Figs. 7C, D, E, F) can be subdivided into:

1. Layers without important chemical gaps nor truly bimodal composition, which extend from rhyolites (usually dominant) to ferrobasalts (Fig. 7C) or even Mg-rich tholeiites (Fig. 6B);

2. Truly bimodal layers (Figs. 7D, E, F; Fig. 6A) with wellidentified acidic (rhyolitic or icelanditic) and basic (basaltic or ferrobasaltic) end-members separated by important chemical gaps, especially at the level of tholeiitic andesites.

The proportions of the two end-members are highly variable. The intermediate compositions plot near the tie-lines connecting the compositions of the two end-members, especially when the basic end-member is ferrobasaltic (Figs. 7C, D); however, when it is truly basaltic (Figs. 7E, F), the intermediate glass shards plot above these tie-lines, and are usually enriched in
$\mathrm{TiO}_{2}$ and $\mathrm{FeO}^{*}$ with respect to the basaltic end-member (Fig. 7E). In such cases, their composition cannot be ascribed to simple magma mixing processes.

Similar chemical heterogeneities were identified in a number of onland tephra occurrences (Hildreth, 1981). Bimodal chemical associations are especially common in the Tertiary magmatism of the North Atlantic (Thompson, 1980; Taylor et al., 1980; Vogel, 1982). Several Quaternary heterogeneous tephra emitted by Icelandic volcanoes were also studied in detail (Sigurdsson and Sparks, 1981; Blake, 1984; McGarvie, 1984; Mork 1984) and interpreted in terms of a combination of magma mixing and fractional crystallization processes in zoned magma chambers, sometimes with additional wall-rock contamination (Macdonald et al., 1987).

\section{Chemical variation within heterogeneous layers}

The trends shown in Figures 6A and 7 are typically tholeiitic, and are characterized by regular increases of $\mathrm{SiO}_{2}$ and alkalis. The total iron and $\mathrm{TiO}_{2}$ contents increase from $\mathrm{Mg}$-rich basalts to ferrobasalts and decrease in the more $\mathrm{Mg}$-poor glasses. This conclusion can be extended to all the heterogeneous Leg 104 tephra layers, as shown by selected individual analyses of glass shards from Sites 642, 643, and 644 (Table 6) as well as by Fig- 


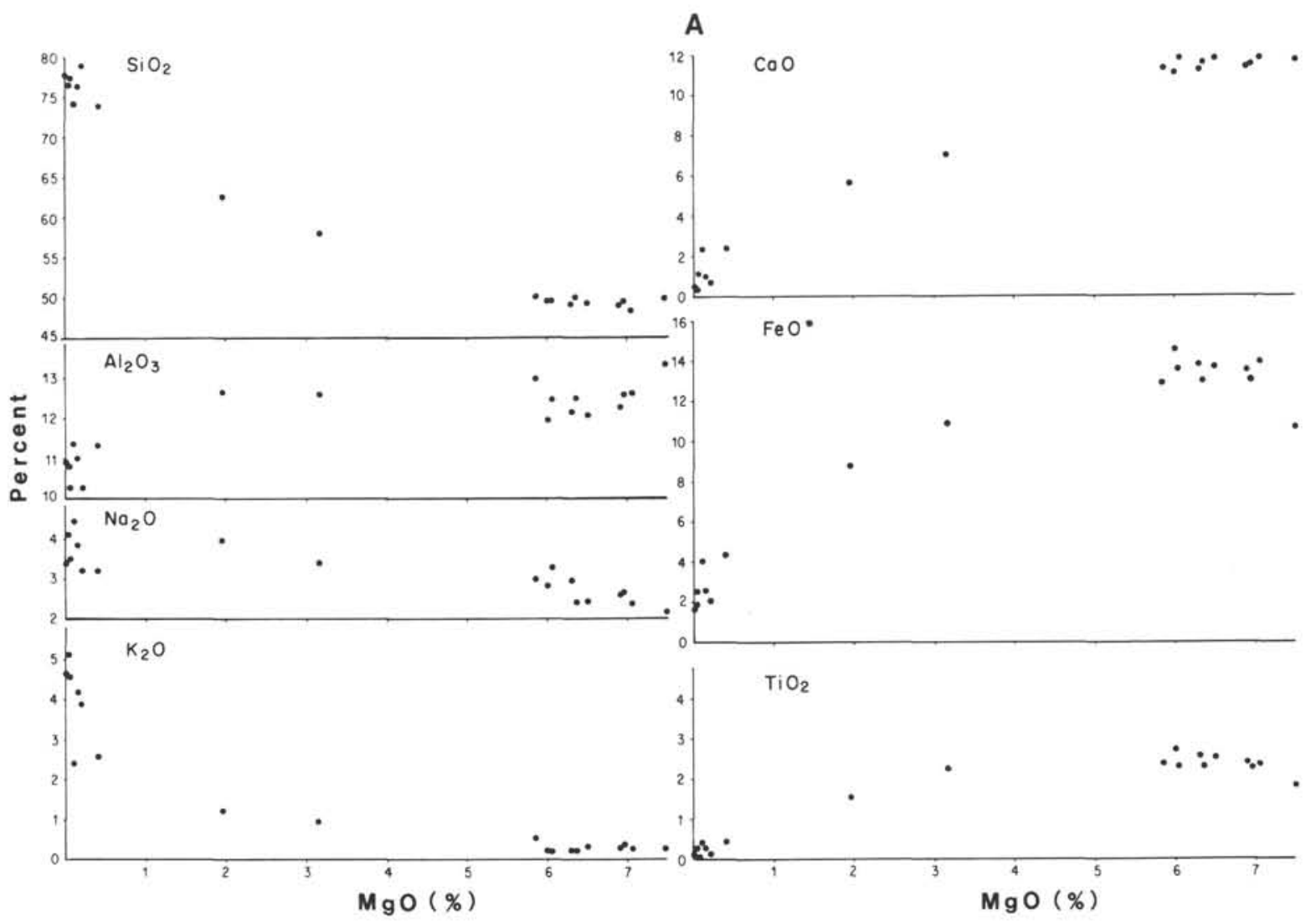

B

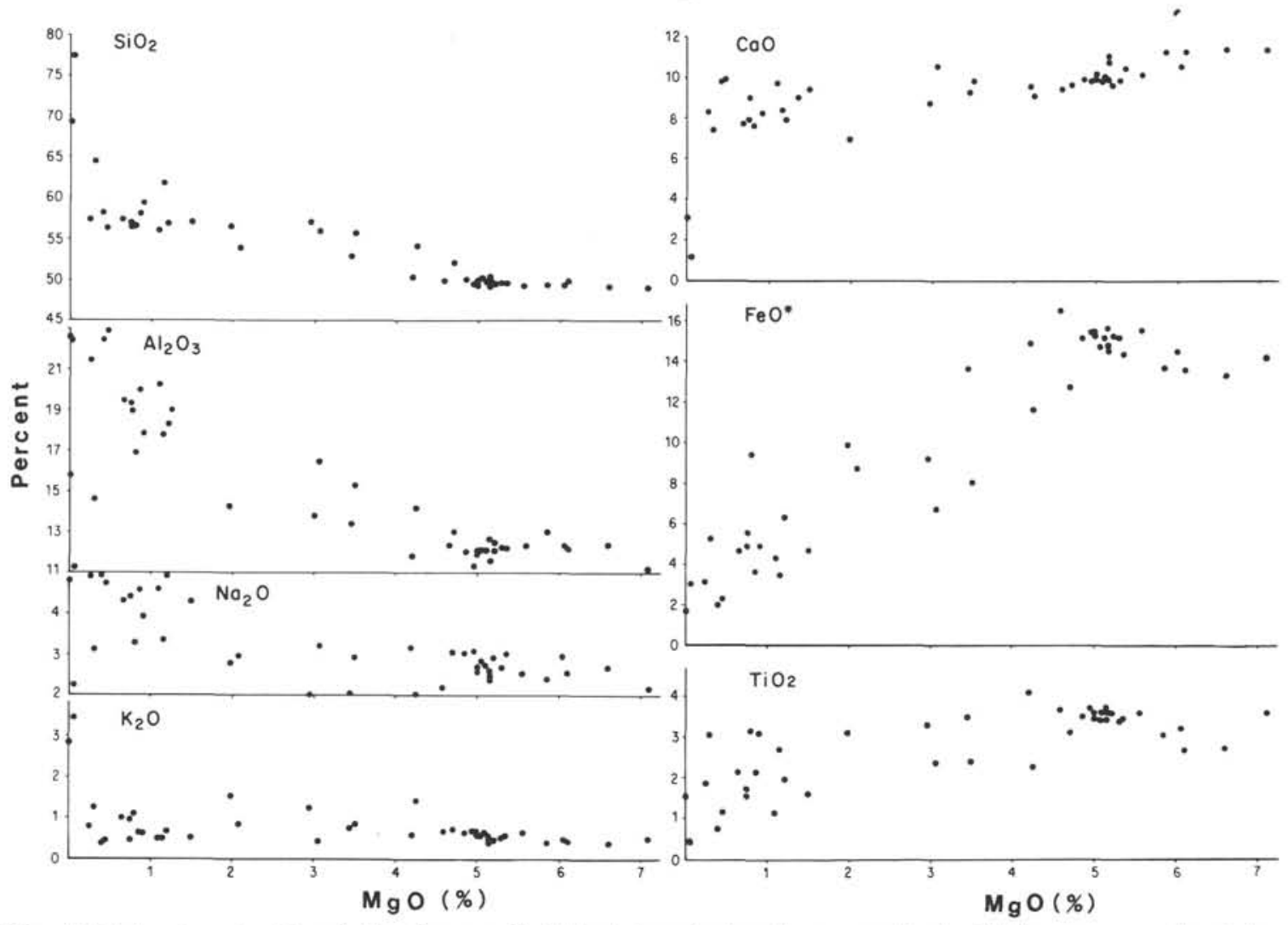

Figure 6. Major-element oxide variation diagrams. Individual glass shard analyses normalized to 100 for two composite ash layers. A. Sample 104-643A-28X-01, 67-68 cm: fresh glasses range in composition from basalt to rhyolite. B. Sample 104-642D-7X-06, $70-71 \mathrm{~cm}$ : basic glasses are fresh, but acid glasses are altered and show characteristic relative enrichment in $\mathrm{Al}_{2} \mathrm{O}_{3}$ and depletion in alkalies, especially $\mathrm{K}_{2} \mathrm{O}$. 
Table 4. Alteration of volcanic glass shards of rhyolitic (analyses 1 to 8 ) and basic (analyses 8 to 16) compositions. Individual SEM/ EDS analyses normalized to 100. FG: fresh glass; AG: altered glass; HAG: highly altered glass.

\begin{tabular}{|c|c|c|c|c|c|c|c|c|c|c|c|c|c|c|c|c|}
\hline \multirow{2}{*}{$\begin{array}{l}\text { Sample } \\
\text { Analysis } \\
\text { Type }\end{array}$} & \multicolumn{2}{|c|}{$\begin{array}{c}104-643 \mathrm{~A} \\
16-6, \\
48-49 \mathrm{~cm}\end{array}$} & \multicolumn{2}{|c|}{$\begin{array}{l}-642 C-7-1 \\
133-135 \mathrm{~cm}\end{array}$} & \multicolumn{4}{|c|}{$-643 \mathrm{~A}-28-2,149-150 \mathrm{~cm}$} & \multicolumn{2}{|c|}{$\begin{array}{l}-643 \mathrm{~A}-22-3 \\
110-112 \mathrm{~cm}\end{array}$} & \multicolumn{2}{|c|}{$\begin{array}{l}-642 \mathrm{D}-7-2 \\
132-133 \mathrm{~cm}\end{array}$} & \multicolumn{4}{|c|}{$-642 \mathrm{D}-8-1,119-120 \mathrm{~cm}$} \\
\hline & $\begin{array}{c}1 \\
\text { FG }\end{array}$ & $\begin{array}{c}2 \\
\mathrm{AG}\end{array}$ & $\stackrel{3}{\mathrm{FG}}$ & $\stackrel{4}{\mathrm{HAG}}$ & $\begin{array}{c}5 \\
\text { FG }\end{array}$ & $\begin{array}{c}6 \\
\mathrm{AG}\end{array}$ & $\begin{array}{c}7 \\
\text { HAG }\end{array}$ & $\begin{array}{c}8 \\
\text { HAG }\end{array}$ & $\stackrel{9}{\text { FG }}$ & $\begin{array}{r}10 \\
A G\end{array}$ & $\begin{array}{c}11 \\
\text { FG }\end{array}$ & $\begin{array}{r}12 \\
A G\end{array}$ & $\begin{array}{r}13 \\
\text { FG }\end{array}$ & $\begin{array}{c}14 \\
\text { HAG }\end{array}$ & $\begin{array}{c}15 \\
\mathrm{HAG}\end{array}$ & $\begin{array}{c}16 \\
\text { HAG }\end{array}$ \\
\hline $\mathrm{SiO}_{2}$ & 75.37 & 66.30 & 77.27 & 60.37 & 78.62 & 65.80 & 60.52 & 59.29 & 51.58 & 57.98 & 48.72 & 55.10 & 50.55 & 53.60 & 57.43 & 55.18 \\
\hline $\mathrm{TiO}_{2}$ & 0.28 & 0.32 & 0.23 & 0.37 & 0.10 & 1.41 & 3.80 & 2.14 & 3.20 & 2.30 & 3.77 & 4.22 & 3.81 & 0.77 & 0.70 & 0.37 \\
\hline $\mathrm{Al}_{2} \mathrm{O}_{3}$ & 13.04 & 18.10 & 11.36 & 13.16 & 11.06 & 13.45 & 11.25 & 9.80 & 12.76 & 17.90 & 12.66 & 15.64 & 12.64 & 15.18 & 6.69 & 5.40 \\
\hline $\mathrm{Fe}_{2} \mathrm{O}_{3}{ }^{*}$ & & 10.10 & & 18.35 & & 11.19 & 17.85 & 19.62 & & 6.49 & & 11.15 & & 18.97 & 24.81 & 27.28 \\
\hline $\mathrm{FeO}^{*}$ & 2.58 & & 3.19 & & 2.00 & & & & 14.62 & & 15.56 & & 12.34 & & & \\
\hline $\mathrm{MnO}_{2}$ & 0.13 & 0.47 & 0.12 & - & 0.09 & 0.56 & - & 0.10 & 0.43 & 0.16 & 0.31 & 0.07 & 0.30 & 0.07 & - & - \\
\hline $\mathrm{MgO}^{2}$ & 0.24 & 1.32 & 0.04 & 4.19 & 0.02 & 3.18 & 2.08 & 3.75 & 4.36 & 1.73 & 5.16 & 2.01 & 5.12 & 2.87 & 4.10 & 3.89 \\
\hline $\mathrm{CaO}$ & 1.10 & 1.73 & 1.05 & 1.63 & 0.40 & 0.63 & 0.77 & 0.30 & 9.24 & 8.64 & 10.13 & 6.73 & 10.43 & 0.16 & 0.51 & 0.38 \\
\hline $\mathrm{NaO}_{2}$ & 2.45 & 0.39 & 2.75 & 0.26 & 2.51 & 0.61 & 0.29 & 0.33 & 2.93 & 3.89 & 2.87 & 3.82 & 3.61 & 0.91 & 0.27 & 0.12 \\
\hline $\mathrm{K}_{2} \mathrm{O}^{2}$ & 4.48 & 0.84 & 3.62 & 1.41 & 4.85 & 2.20 & 3.07 & 4.13 & 0.43 & 0.61 & 0.61 & 1.13 & 0.70 & 7.47 & 5.49 & 7.38 \\
\hline $\mathrm{P}_{2} \mathrm{O}_{5}$ & 0.33 & 0.43 & 0.37 & 0.26 & 0.35 & 0.97 & 0.37 & 0.54 & 0.45 & 0.30 & 0.21 & 0.13 & 0.50 & - & - & - \\
\hline
\end{tabular}

Table 5. Smectite and glauconite structural formulas (basis: 11 oxygens) from Table 4 analyses.

\begin{tabular}{|c|c|c|c|c|c|c|c|}
\hline & Analysis & 4 & 7 & 8 & 14 & 15 & 16 \\
\hline \multirow{3}{*}{ IV } & $\mathrm{Si}$ & 3.81 & 3.98 & 3.91 & 3.57 & 3.83 & 3.76 \\
\hline & $\mathrm{Al}$ & 0.19 & 0.02 & 0.09 & 0.43 & 0.17 & 0.24 \\
\hline & $\mathrm{Al}$ & 0.78 & 0.85 & 0.67 & 0.75 & 0.34 & 0.19 \\
\hline \multirow[t]{5}{*}{ VI } & $\mathrm{Fe}^{3+}$ & 0.87 & 0.88 & 0.97 & 0.95 & 1.25 & 1.39 \\
\hline & $\mathrm{Mg}$ & 0.44 & 0.21 & 0.37 & 0.28 & 0.41 & 0.39 \\
\hline & $\mathrm{Ca}$ & 0.11 & 0.05 & 0.02 & 0.01 & 0.04 & 0.03 \\
\hline & $\mathrm{Na}$ & 0.03 & 0.04 & 0.04 & 0.12 & 0.03 & 0.02 \\
\hline & K & 0.11 & 0.26 & 0.35 & 0.63 & 0.47 & 0.64 \\
\hline
\end{tabular}

ure 8. In this figure, the mean analysis of each compositional group (for a given sample) has been plotted against $\mathrm{MgO}$ contents. The $\mathrm{FeO}^{*}$ and $\mathrm{TiO}_{2}$-rich character of the intermediate composition is compatible with an origin by fractional crystallization, but cannot be explained by only mixing Mg-rich basaltic and rhyolitic magmas. The trends are very similar to those of the heterogeneous ejecta of the 1875 eruption of Askja, Iceland (Sigurdsson and Sparks, 1981). Thus we suggest that many of the heterogeneous Leg 104 ash layers originated from similar kinds of eruptions. According to Sigurdsson and Sparks (1981), the 1875 Askja eruption was caused by the ascent of tholeiitic basalt magma within a density-stratified magma chamber with a rhyolitic upper part, a ferrobasaltic lower part, and an intervening layer of icelandite. Within such a magmatic system, different eruption scenarios characterized by variable withdrawal dynamics from different density levels of the stratified magma chamber and variable inputs from the ascending basaltic magmas (Sparks et al., 1977; Hildreth, 1981; Blake, 1981; Baker and McBirney, 1985; Blake and Ivey, 1986) may account for most of the chemical distributions depicted in Figures $7 \mathrm{~A}$ to $\mathrm{F}$. The problem of the respective roles of magma mixing and fractional crystallization in the genesis of tephra of intermediate composition is difficult to ascertain from a single (some centimeters thick) cored deposit of a given eruptive event. However, the lack of linear trends from basalts to rhyolites (for $\mathrm{FeO}^{*}$ and $\mathrm{TiO}_{2}$ ), and the apparent homogeneity of the compositions of intermediate glass shards lead us to believe that true hybrid glasses are uncommon in the Leg 104 ash layers.

\section{Compositional variations within the ash layer sequences}

Table 1 data indicate that both rhyolitic and heterogeneous ash layers were deposited throughout the Cenozoic horizons cored during Leg 104. However, basic tephra are mostly of early Miocene age: seven of the nine predominantly basic tephra layers investigated are intercalated within lower Miocene sediments, one layer (104-642C-21H-06, 4-7 cm) occurs in the middle Miocene, and there is a single case of predominantly basic ash layer of Pleistocene age (Sample 104-642B-9H-03, 95-96 cm). Thus, most of the basaltic glass shards (analyses in Table 6) are from lower Miocene ash horizons.

Sigurdsson and Loebner (1981) emphasized the coexistence of two kinds of tholeiitic series, low-K and high-K, throughout the Cenozoic ash layers in the North Atlantic. However, little dispersion is observed in the $\mathrm{K}_{2} \mathrm{O}$ contents of glass shards ranging from high-Mg basalts to icelandites (Table 6) as well as in the $\mathrm{K}_{2} \mathrm{O}-\mathrm{MgO}$ diagram (Fig. 8) for the same range. In contrast, there is obviously a great scatter in the $\mathrm{K}_{2} \mathrm{O}$ contents of rhyolites (Fig. 8). According to Sigurdsson and Loebner's (1981) criteria, three of the seven representative analyses of rhyolitic glasses given in Table 6 can be classified as low-K rhyolites $\left(\mathrm{K}_{2} \mathrm{O}<3.8 \%\right)$, and four as high-K rhyolites (including three slightly peralkaline compositions with small amounts of normative acmite). Low-K, high-K (non-peralkaline) and high-K peralkaline rhyolitic compositions are found in lower Miocene Leg 104 ash layers, and the two former types only occur in middle Miocene to Quaternary tephra horizons (Fig. 9). Alkali feldspar phenocrysts are found within the K-rich ash levels (Sigurdsson, 1971).

\section{MAJOR-AND TRACE-ELEMENT DATA OF BULK ASH LAYERS}

Chemical data of bulk ash layers from Site 642 are presented in Table 7 (major elements) and Table 8 (trace elements). It must be remembered that, while most acid compositions (104-642B$13 \mathrm{H}, \mathrm{CC} ; 104-642 \mathrm{C}-18 \mathrm{H}-03,21-22 \mathrm{~cm}$ ) are exclusively rhyolitic tephra (see Table 1), most other ash layers are physical mixtures of rhyolitic glasses plus various amounts of basaltic or intermediate shards. This feature explains the lack of truly basaltic (or even ferrobasaltic) compositions, evidenced by the low $\mathrm{MgO}$, $\mathrm{Ni}$, and $\mathrm{Cr}$ contents. Thus all the major-element compositions show almost linear correlations between intermediate tholeiitic andesite and rhyolite endmembers. However, a comparison of the two truly rhyolitic samples shows significant differences in $\mathrm{K}_{2} \mathrm{O}$, total iron, and $\mathrm{CaO}$ contents, consistent with their respectively high-K and low-K affinities (Sigurdsson and Loebner, 1981).

Some trace elements are plotted against Th contents in Figure 10. The progressive increase in the proportion of rhyolitic component corresponds to a regular decrease of $\mathrm{Sc}$ (as well as other compatible trace elements). $\mathrm{La}, \mathrm{Ta}$, and $\mathrm{Hf}$ show roughly linear positive correlations passing through the origin, and are thus compatible with a fractional crystallization process. However, the K-rich rhyolitic Section 104-642B-13H, CC is significantly depleted in $\mathrm{Ta}$ and $\mathrm{Hf}$ with respect to other samples, and thus may be derived from a different kind of source. 


\section{A. DESPRAIRIES ET AL.}

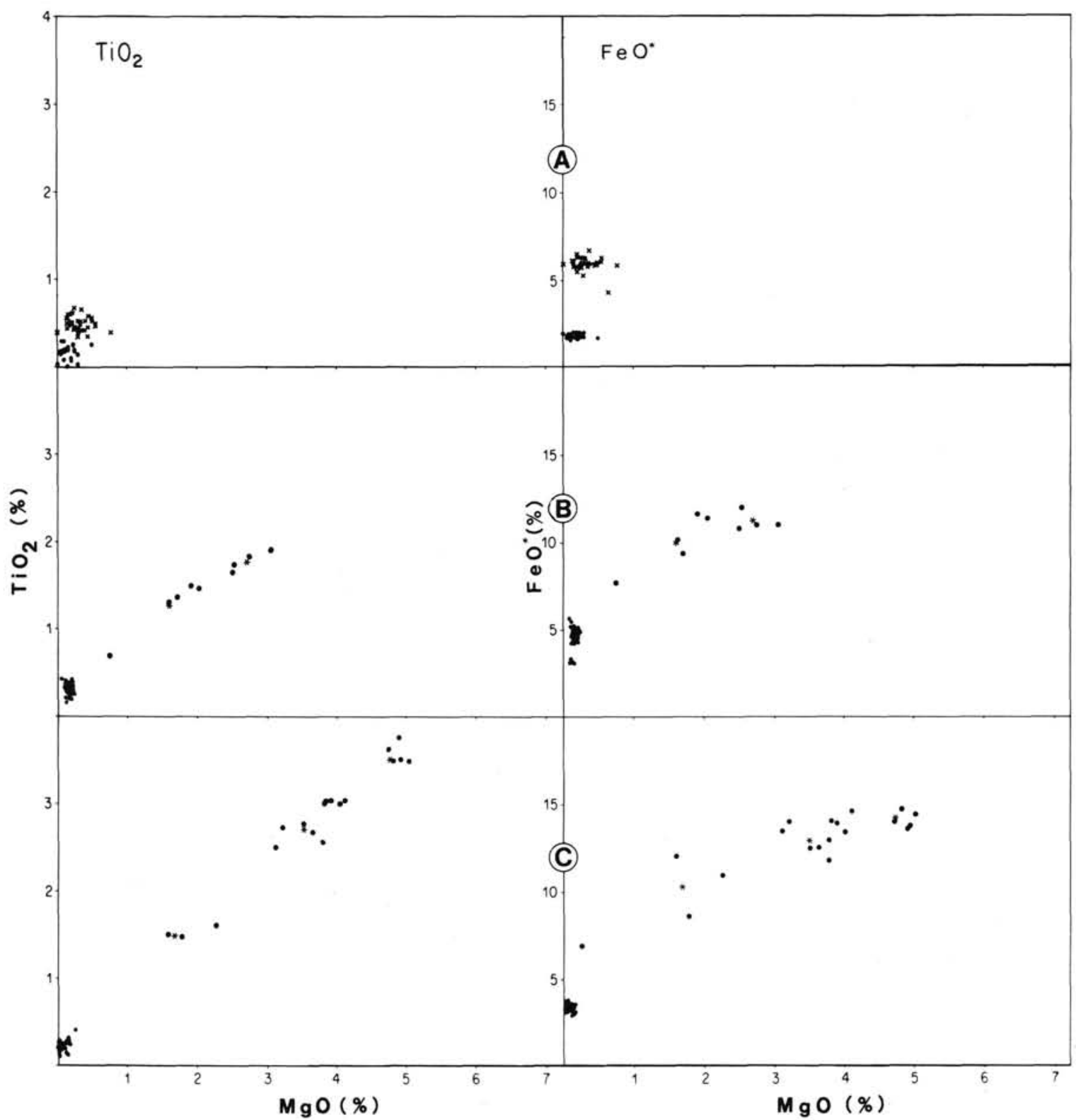

Figure 7. $\mathrm{TiO}_{2}$ and $\mathrm{FeO}^{*}$ vs. $\mathrm{MgO}$ variations in glasses within different types of ash layers. $\mathrm{FeO} *$ : total iron as $\mathrm{FeO}$. Points and crosses: individual glass shards analyses normalized to 100 . Asterisks: mean analyses of compositional groups as defined by $\mathrm{MgO}$ boundaries (see text for discussion). A: Samples 104-644B-11 H-02, 36-37 cm (•) and 104-643A-11X-02, 76-77 cm (X). B: Sample 104-642C-15H-04, 87-88 cm. C: Sample 104-642C-19H-03, 71-74 cm D: Sample 104-642B-9H-03, 95-96 cm E: Sample 104-643A-28X-01, 67-68 cm

The chondrite-normalized REE spectras shown in Figure 11 reflect the LREE-enriched character of all the samples and the increase of REE concentrations with silica content. The rhyolitic Sample 104-642B-13H, CC again differs from others by its higher $\mathrm{La} / \mathrm{Sm}$ or $\mathrm{La} / \mathrm{Tb}$ ratios and its more pronounced negative Eu anomaly. The REE spectras are compatible with a tholeiitic (E-MORB or transitional) parentage, as well as the major-element patterns (Fig. 8). This is also evidenced by the location of the points corresponding to Leg 104 bulk ash layers analyses in the Hf/Th/Ta diagram (Fig. 12). With the exception of the K-rich rhyolitic Sample 104-642B-13H, CC, all samples plot in the field of LREE-enriched MORB and transitional basalts, as do most of the Tertiary and Quaternary Icelandic lavas (Wood, 1980; Wood et al., 1979). This homogeneity contrasts with the scatter of some DSDP Leg 81 ash-layer analyses (shown as crosses in Fig. 12), which plot either in the same field (81-37), or in fields of normal MORB (81-29), alkali basalt series (81$62)$, or even calc-alkaline series (81-89). The chemical variability of Leg 81 ash horizons is also illustrated in Table 9 and by the REE spectras shown in Figure 11.

\section{CONCLUSIONS}

\section{Diagenetic Evolution}

The distribution of argillized glasses through the cored sedimentary sequences of ODP Leg 104 shows no relationship with age. The tephra horizons occur within a variety of lithologies (terrigenous muds, carbonate or siliceous oozes) and the degree of glass alteration cannot be directly related to a specific type of surrounding sediment. In general, there is little evidence of 


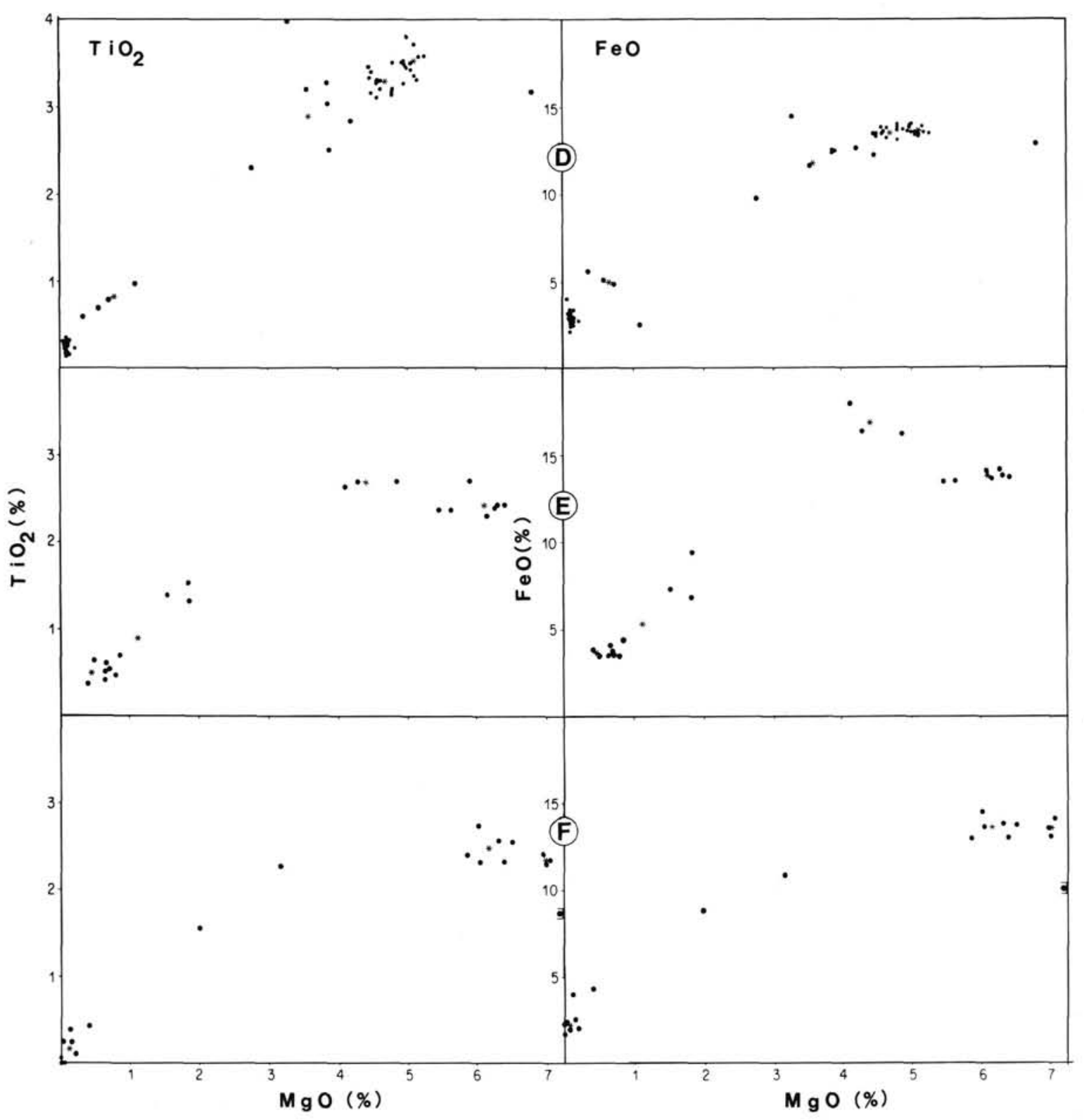

Figure 7 (continued).

postburial diagenetic effects in the Quaternary to lower Miocene sedimentary sequences (Froget et al., this volume). An important condition leading to glauconite formation, other than the water depth, is the time that sediments are exposed to normal seawater, a function of sedimentation rate. Slow sedimentation rate prevailed in the case of one glauconitized ash layer from Hole 642D (Sample 104-642D-11X-01, 94-104 cm) cemented by apatite and interpreted as a hardground formed over an extended period of time (Eldholm, Thiede, Taylor, et al., 1987). On the basis of the chemical composition of unaltered glasses, two glauconite-rich ash layers of this hole (Samples 104642D-7X-06, 72-74 cm and 104-642D-8X-01, 118-121 cm) can be correlated with tephra horizons of Site 643 (Samples 104$643 \mathrm{~A}-28 \mathrm{X}-01,67-68 \mathrm{~cm}$ and 104-643A-28X-02, 148-150 cm) containing both iron-smectite and glauconite (Table 1, Fig. 4).

We propose that the alteration of glasses of Quaternaryearly Miocene age took place during an early diagenetic phase, penecontemporaneous with the formation of deposits. The difference between smectite and glauconite genesis only reflects the duration of exposure of glasses at the interface with seawater; i.e., the rapidity of burial, which depends on the depositional environment conditions.

From this interpretation, the occurrence of glasses altered to smectite or glauconite reflects multiple short-ranging hiatuses or major unconformities, also identified biostratigraphically (Eldholm, Thiede, Taylor, et al., 1987). Postburial diagenesis is, however, observed in pyroclastic material of Oligocene-Eocene age. This material is marked by the increasing development of Fe-Mg smectite (saponite) and Fe-Mg illite with increasing age. This latter mineral has been interpreted (Froget et al., this volume) as a diagenetic postburial product probably derived from an ironrich smectite precursor, but formed later than the glauconite.

\section{Magmatic Evolution}

All the ash layers investigated, except one, can be related to a single broad type of magmatic series, i.e., to LREE-enriched MORB and derivative melts. Leg 104 ash layers are much more homogeneous than those cored during DSDP Leg 81 on the margins of Rockall Plateau. The chemical similarities of Leg 104 tephra to the ejecta of the main Icelandic Neogene and 
Table 6. Representative individual analyses of glass shards from Leg 104 ash layers. Analyses recalculated to $100 \%$; FeO*: total iron as FeO. C.I.P.W. normative parameters calculated with $15 \%$ total iron ad $\mathrm{Fe}_{2} \mathrm{O}_{3}$ and $85 \%$ as $\mathrm{FeO}$.

\begin{tabular}{|c|c|c|c|c|c|c|c|c|c|c|c|c|c|c|}
\hline \multirow{5}{*}{$\begin{array}{l}\text { Type } \\
\text { Anal. no. } \\
\text { Hole } \\
\text { Core } \\
\text { Interval }(\mathrm{cm})\end{array}$} & \multicolumn{4}{|c|}{ High-Mg basalts } & \multicolumn{5}{|c|}{ Low-Mg basalts } & \multicolumn{5}{|c|}{ Ferro-basalts } \\
\hline & 1 & 2 & 3 & 4 & 5 & 6 & 7 & 8 & 9 & 10 & 11 & 12 & 13 & 14 \\
\hline & $643 \mathrm{~A}$ & $643 \mathrm{~A}$ & $643 \mathrm{~A}$ & 642D & $643 \mathrm{~A}$ & $643 \mathrm{~A}$ & $643 \mathrm{~A}$ & $642 \mathrm{D}$ & $642 B$ & 642B & $642 \mathrm{C}$ & $643 \mathrm{~A}$ & $643 \mathrm{~A}$ & 642D \\
\hline & $28-2$ & $25 \mathrm{CC}$ & $28-1$ & $7-6$ & $28-1$ & $19-1$ & $22-3$ & $7-6$ & $9-3$ & $9-3$ & $21-6$ & $19-1$ & $22-3$ & $11-1$ \\
\hline & $149-150$ & $11-12$ & $67-68$ & $70-71$ & $67-68$ & $48-49$ & $110-112$ & $70-71$ & $95-96$ & $95-96$ & $4-7$ & $48-49$ & $110-112$ & $87-88$ \\
\hline $\mathrm{SiO}_{2}$ & 51.32 & 49.49 & 49.28 & 48.97 & 49.87 & 50.31 & 49.09 & 49.55 & 50.75 & 51.80 & 49.79 & 49.83 & 51.62 & 53.49 \\
\hline $\mathrm{TiO}_{2}$ & 1.74 & 2.17 & 2.35 & 3.23 & 2.48 & 2.43 & 2.85 & 3.36 & 3.62 & 3.36 & 3.66 & 2.68 & 3.20 & 3.38 \\
\hline $\mathrm{Al}_{2} \mathrm{O}_{3}$ & 14.10 & 12.57 & 12.62 & 11.79 & 12.40 & 12.49 & 12.31 & 12.28 & 13.03 & 12.89 & 13.66 & 12.83 & 12.76 & 12.72 \\
\hline $\mathrm{FeO} *^{3}$ & 10.05 & 13.32 & 13.56 & 13.88 & 13.61 & 13.89 & 15.60 & 14.79 & 13.83 & 13.67 & 14.14 & 16.95 & 14.65 & 12.88 \\
\hline $\mathrm{MnO}$ & 0.30 & 0.20 & 0.26 & 0.29 & 0.30 & 0.27 & 0.25 & 0.25 & 0.25 & 0.25 & 0.21 & 0.33 & 0.34 & 0.24 \\
\hline $\mathrm{MgO}$ & 7.70 & 7.11 & 7.00 & 6.88 & 6.17 & 6.12 & 5.66 & 5.44 & 5.21 & 4.77 & 4.54 & 4.41 & 4.36 & 4.20 \\
\hline $\mathrm{CaO}$ & 11.93 & 12.10 & 11.62 & 11.41 & 11.59 & 11.30 & 10.38 & 10.40 & 8.93 & 8.63 & 9.33 & 10.24 & 9.25 & 8.07 \\
\hline $\mathrm{Na}_{2} \mathrm{O}$ & 2.21 & 2.36 & 2.57 & 2.42 & 2.82 & 2.52 & 3.01 & 2.68 & 3.26 & 3.29 & 3.14 & 2.15 & 2.94 & 2.86 \\
\hline $\mathrm{K}_{2} \mathrm{O}$ & 0.24 & 0.20 & 0.29 & 0.46 & 0.29 & 0.32 & 0.45 & 0.49 & 0.70 & 0.81 & 0.96 & 0.46 & 0.43 & 1.02 \\
\hline $\mathrm{P}_{2} \mathrm{O}_{5}$ & 0.41 & 0.48 & 0.45 & 0.67 & 0.47 & 0.35 & 0.40 & 0.76 & 0.42 & 0.53 & 0.57 & 0.12 & 0.45 & 1.14 \\
\hline Q & 2.35 & & & 0.40 & & 1.54 & & 2.22 & 1.80 & 3.46 & 0.85 & 3.75 & 5.27 & 9.39 \\
\hline Or & 1.41 & 1.18 & 1.71 & 2.71 & 1.71 & 1.88 & 2.65 & 2.88 & 4.12 & 4.77 & 5.65 & 2.71 & 2.53 & 6.00 \\
\hline $\mathrm{Ab}$ & 18.65 & 19.90 & 21.67 & 20.39 & 23.77 & 21.25 & 25.37 & 22.58 & 27.49 & 27.73 & 26.47 & 18.13 & 24.78 & 24.09 \\
\hline An & 27.78 & 23.04 & 21.98 & 19.88 & 20.26 & 21.76 & 18.69 & 19.96 & 18.80 & 17.96 & 20.28 & 23.93 & 20.29 & 18.78 \\
\hline OI & & 0.16 & 2.95 & & 0.66 & & 3.97 & & & & & & & \\
\hline D.I. & 22.41 & 21.08 & 23.38 & 23.51 & 25.48 & 24.68 & 28.02 & 27.68 & 33.41 & 35.96 & 32.97 & 24.58 & 32.58 & 39.47 \\
\hline S.I. & 37.56 & 30.66 & 29.56 & 28.75 & 26.61 & 26.47 & 22.67 & 23.00 & 22.41 & 20.93 & 19.75 & 18.15 & 19.19 & 19.81 \\
\hline
\end{tabular}

\begin{tabular}{|c|c|c|c|c|c|c|c|c|c|c|c|c|c|c|c|}
\hline \multirow{4}{*}{$\begin{array}{l}\text { Type } \\
\text { Anal. no. } \\
\text { Hole } \\
\text { Core } \\
\text { Interval }(\mathrm{cm})\end{array}$} & \multicolumn{4}{|c|}{ Basaltic andesites } & \multicolumn{4}{|c|}{ Icelandites } & \multicolumn{7}{|c|}{ Rhyolites } \\
\hline & 15 & $\begin{array}{c}16 \\
642 C\end{array}$ & 17 & 18 & 19 & $\begin{array}{c}20 \\
642 \mathrm{C}\end{array}$ & 21 & 22 & $\begin{array}{c}23 \\
643 A\end{array}$ & $\begin{array}{c}24 \\
644 \mathrm{~B}\end{array}$ & $\begin{array}{c}25 \\
643 \mathrm{~A}\end{array}$ & $\begin{array}{c}26 \\
643 \mathrm{~A}\end{array}$ & $\begin{array}{c}27 \\
642 \mathrm{C}\end{array}$ & $\begin{array}{c}28 \\
642 B\end{array}$ & $\begin{array}{c}29 \\
643 \mathrm{~A}\end{array}$ \\
\hline & $\begin{array}{c}642 \mathrm{~B} \\
9-3\end{array}$ & $\begin{array}{c}642 C \\
21-6\end{array}$ & $\begin{array}{c}642 \mathrm{D} \\
8-4\end{array}$ & $\begin{array}{c}642 \mathrm{~B} \\
21-2\end{array}$ & $\begin{array}{c}642 \mathrm{~B} \\
21-2\end{array}$ & $\begin{array}{c}642 \mathrm{C} \\
15-6\end{array}$ & 643A & $\begin{array}{c}642 \mathrm{C} \\
21-6\end{array}$ & $\begin{array}{c}643 \mathrm{~A} \\
11-2\end{array}$ & $\begin{array}{c}644 \mathrm{~B} \\
11-3\end{array}$ & $\begin{array}{c}643 \mathrm{~A} \\
8-3\end{array}$ & $\begin{array}{c}643 \mathrm{~A} \\
2-3\end{array}$ & $\begin{array}{c}642 \mathrm{C} \\
19-3\end{array}$ & $\begin{array}{l}642 \mathrm{~B} \\
21-2\end{array}$ & $\begin{array}{c}643 A \\
28-2\end{array}$ \\
\hline & $95-96$ & 4-7 & $23-24$ & $136-137$ & $136-137$ & $81-82$ & $48-49$ & $4-7$ & $76-77$ & $36-37$ & $125-126$ & $74-75$ & $71-74$ & $136-137$ & $149-150$ \\
\hline $\mathrm{SiO}_{2}$ & 54.53 & 53.99 & 55.32 & 55.20 & 61.54 & 69.12 & 71.89 & 67.71 & 70.34 & 73.31 & 74.67 & 76.00 & 79.17 & 72.26 & 77.32 \\
\hline $\mathrm{TiO}_{2}$ & 3.19 & 3.75 & 2.70 & 2.78 & 2.19 & 0.98 & 0.89 & 0.88 & 0.48 & 0.15 & 0.19 & 0.27 & 0.14 & 0.34 & 0.11 \\
\hline $\mathrm{Al}_{2} \mathrm{O}_{3}$ & 13.63 & 14.89 & 11.77 & 12.70 & 13.39 & 13.83 & 12.40 & 14.09 & 12.67 & 13.52 & 12.93 & 11.35 & 11.08 & 11.58 & 10.87 \\
\hline $\mathrm{FeO}^{*}$ & 12.32 & 10.77 & 14.05 & 12.77 & 8.98 & 5.21 & 5.33 & 7.20 & 5.83 & 1.73 & 2.46 & 3.24 & 1.54 & 4.72 & 1.96 \\
\hline $\mathrm{MnO}$ & 0.15 & 0.24 & 0.30 & 0.31 & 0.18 & 0.11 & 0.18 & 0.17 & 0.18 & 0.12 & 0.08 & 0.08 & 0.04 & 0.19 & 0.07 \\
\hline $\mathrm{MgO}$ & 3.52 & 3.28 & 3.23 & 3.02 & 1.64 & 1.37 & 1.12 & 0.97 & 0.28 & 0.17 & 0.12 & 0.07 & 0.06 & 0.06 & 0.02 \\
\hline $\mathrm{CaO}$ & 7.59 & 7.92 & 7.80 & 7.62 & 6.11 & 2.88 & 3.34 & 3.30 & 2.80 & 0.72 & 0.80 & 1.35 & 0.97 & 1.19 & 0.39 \\
\hline $\mathrm{Na}_{2} \mathrm{O}$ & 3.41 & 3.00 & 2.77 & 2.60 & 2.32 & 3.67 & 2.57 & 2.83 & 4.40 & 4.81 & 4.09 & 4.39 & 3.13 & 5.29 & 4.14 \\
\hline $\mathrm{K}_{2} \mathrm{O}$ & 1.19 & 1.28 & 0.84 & 1.60 & 2.35 & 2.68 & 1.90 & 2.80 & 2.83 & 5.25 & 4.57 & 2.95 & 3.46 & 3.99 & 4.77 \\
\hline $\mathrm{P}_{2} \mathrm{O}_{5}$ & 0.47 & 0.88 & 1.22 & 1.40 & 1.30 & 0.15 & 0.38 & 0.05 & 0.19 & 0.22 & 0.09 & 0.30 & 0.41 & 0.38 & 0.35 \\
\hline Q & 7.68 & 9.96 & 13.28 & 12.63 & 23.17 & 26.95 & 38.82 & 27.98 & 25.76 & 23.43 & 30.21 & 35.47 & 45.64 & 25.40 & 36.43 \\
\hline Or & 7.01 & 7.54 & 4.94 & 9.41 & 13.83 & 15.82 & 11.21 & 16.52 & 16.70 & 31.00 & 26.98 & 17.41 & 20.42 & 23.52 & 28.15 \\
\hline $\mathrm{Ab}$ & 28.76 & 25.29 & 23.32 & 21.89 & 19.54 & 31.00 & 21.70 & 23.90 & 37.16 & 40.28 & 34.57 & 37.09 & 26.45 & 37.27 & 29.32 \\
\hline An & 18.32 & 23.51 & 17.13 & 18.17 & 19.11 & 13.34 & 14.31 & 16.05 & 6.46 & & 3.43 & 2.56 & 2.40 & & \\
\hline Ac & & & & & & & & & & 0.33 & & & & 2.27 & 0.94 \\
\hline D.I. & 43.44 & 42.78 & 41.54 & 43.93 & 56.54 & 73.77 & 71.73 & 68.40 & 79.62 & 94.71 & 91.77 & 89.97 & 92.50 & 86.19 & 93.90 \\
\hline S.I. & 17.10 & 17.66 & 15.24 & 14.88 & 10.60 & 10.51 & 10.09 & 6.94 & 2.07 & 1.41 & 1.06 & 0.65 & 0.73 & 0.42 & 0.18 \\
\hline
\end{tabular}

Quaternary volcanoes are revealed through chemical analyses (e.g., Wood, 1978; Sigurdsson and Sparks, 1981; Flower et al., 1982).

Throughout the 45 ash horizons investigated, chemically heterogeneous layers dominate over homogeneous or subhomogeneous acidic (rhyolitic or icelanditic) layers. Bimodal distributions are very common, with basic components ranging from $\mathrm{Mg}$-rich basalts to ferrobasalts. In cases where the two endmembers are of very contrasted compositions (rhyolite/basalt), the intermediate compositions usually do not plot on the tie-lines connecting the endmembers, especially for $\mathrm{TiO}_{2}$ and total iron. Therefore, the origin of these latter tephras is not (in the majority of the cases studied) related to hybridization processes, but more likely to differentiation processes in zoned magma chambers. Petrologic models similar to those proposed by Sigurdsson and Sparks (1981) for the 1875 eruption of Askja, involving uprise and mixing of basic magma within a density-stratified magma chamber with a rhyolitic upper part and a ferrobasaltic lower part, seem to account for most of the chemical features of the heterogeneous Leg 104 ash layers.

\section{Possible Sources of Tephra Layers}

The distribution of ODP Leg 104 ash layers records two major volcanic maxima during middle Miocene (14-16 Ma) and late Miocene (7-8 Ma). A rough decrease in the rate of explosive eruptions is deduced for the Miocene to Quaternary section; there is no local evidence for a Pleistocene increase of volcanic activity as postulated by Kennett and Thunell (1975) and Donn and Ninkovich (1980).

\section{Chemical data on Leg 104 ash layers}

Almost all the ash levels studied are of E-MORB parentage. However, three kinds of rhyolites were distinguished in Figure 9: peralkaline rhyolites of early Miocene age, which resemble the middle Oligocene rhyolites described by Sigurdsson and Loebner (1981) from DSDP Leg 38 cores and nonperalkaline low-K and high-K rhyolites, which range in age from middle Miocene to Pleistocene.

There is little doubt that Iceland is the main potential source of the studied ash occurrences; this hypothesis is strongly supported by their chemical similarity with the tephra emitted by Icelandic Quaternary volcanoes. However, Sigurdsson and Loebner (1981) pointed out that Iceland cannot be a plausible source for K-rich rhyolites of Miocene age, because such rocks only occur in the Pliocene and Quaternary Icelandic volcanoes. This conclusion is strongly supported by our data on an upper Miocene K-rich rhyolitic ash layer (Section 104-642B-13H, CC). 


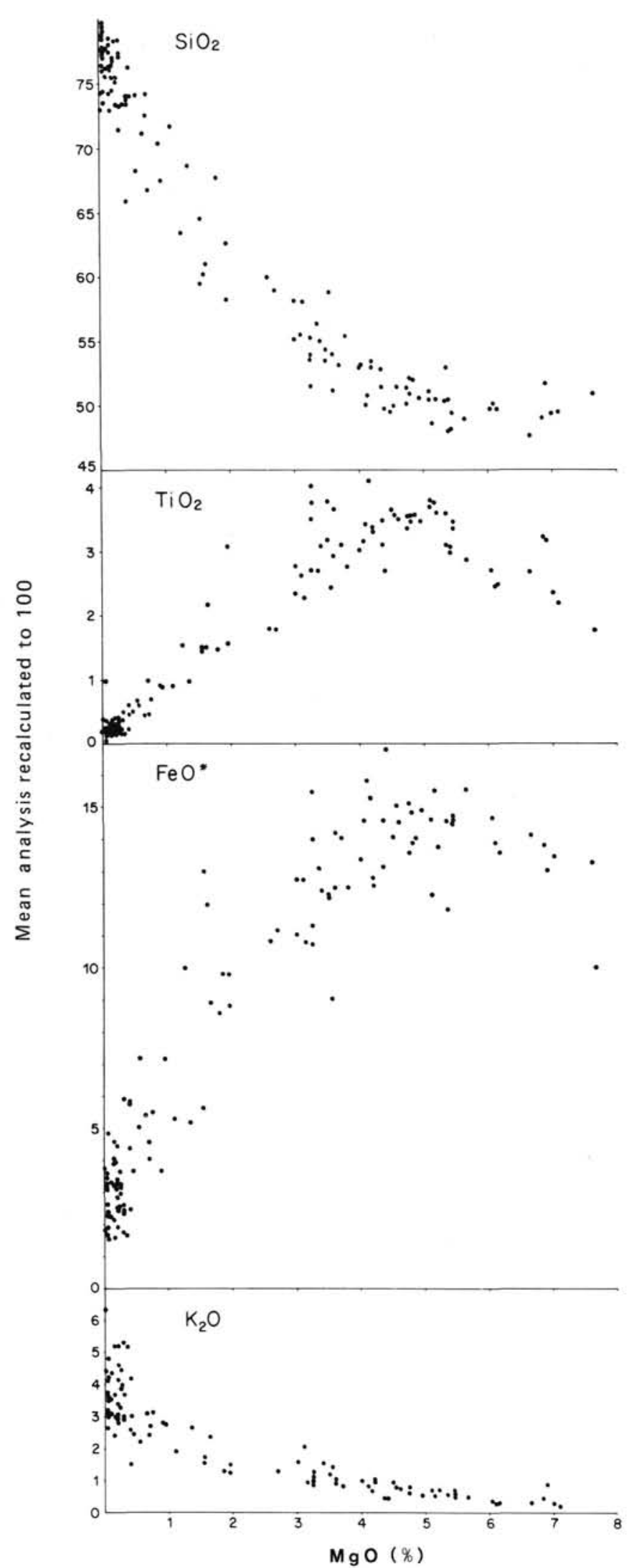

Figure 8. Compiled oxide variation diagrams showing the general trends observed for Leg 104 glass shards. Each point represents, for a given sample, the mean values of the individual (recalculated to 100) glass shard analyses grouped according to the $\mathrm{MgO}$ boundaries defined in the text.
This sample is not cogenetic (even in a very broad sense) with the others, as shown by its hygromagmaphile element contents (Figs. 10 and 11). A calc-aklaline parentage could be considered on the basis of its relatively high $\mathrm{Th} / \mathrm{Ta}$ ratio (3.4) and its plot in the Hf-Th-Ta diagram (Fig. 2). However, this interpretation is not consistent with most of its trace element characteristics, e.g., low $\mathrm{Ba} / \mathrm{La}(=9)$ and high $\mathrm{La} / \mathrm{Th}(=9)$ ratios, which fall in the range of MORB-derived magmas (Gill, 1981, p. 139).

Several hypotheses for the origin of this ash can be considered. First, its relative depletion in Ta and $\mathrm{Hf}$ with respect to Th and La may result from amphibole fractionation during differentiation. This hypothesis cannot be tested because of our lack of knowledge of the differentiation process leading to the rhyolitic ash; however, amphibole fractionation is not an usual feature of the evolution of MORB-derived series. Alternatively, the development of a negative Ta anomaly may result from a contribution of detrital sediments of continental origin, as shown by Grousset et al. (1982). The extreme scarcity of nonvolcanic grains in Section 104-642B-13H-CC does not support this hypothesis. However, depletion in $\mathrm{Ta}$ with respect to $\mathrm{Th}$ and $\mathrm{La}$ may also result from the contribution of continental crust to the genesis of the rhyolitic magmas either by partial melting or contamination. The lower volcanic series drilled at Site 642 exemplify such a crustal contribution (Eldholm, Thiede, Taylor, et al., 1987); the corresponding samples have $\mathrm{Th} / \mathrm{Ta}$ ratios ranging from 6 to 9 (J. L. Joron, unpublished data). We suggest that the unusual chemical characteristics of Section 104-642B-13H-CC (and maybe of other K-rich rhyolitic Miocene ash layers) result from crustal contribution to magma genesis during the rifting of continental crust, e.g., the Jan Mayen Ridge.

\section{Paleogene volcanic evolution (Rockall Plateau)}

Three phases of volcanism were recognized in the Paleogene sequence of the southwest Rockall Plateau (Morton and Keene, 1984).

\section{Phase 1}

Marked by a pile of tholeiitic basalts and hyaloclastites, forms a dipping reflector sequence of Paleocene to early Eocene age, similar to that drilled during ODP Leg 104 (Eldholm, Thiede, Taylor, et al., 1987).

\section{Phase 2}

Is characterized by lower Eocene tuffs of fall origin showing bimodal acidic-basic composition and geochemical characteristics (Sample 81-37, Table 9). This sample plots within the EMORB field in Figure 12, as most of the younger ashes. We suggest a local explosive subaerial source, for this episode, i.e., the elevated part of the Rockall Plateau.

\section{Phase 3}

Is of middle-late Eocene age. Tuffs exclusively made up of tholeiitic basalts were found on Rockall Plateau (Morton and Keene, 1984). Rhyolitic ash layers, usually peralkaline, were recovered on Vøring Plateau (DSDP Leg 38, Sites 340 and 343; Sigurdsson and Loebner, 1981). Glasses of basaltic composition (Sample 81-29, Table 9) plot in the field of N-MORB (Fig. 12). Their petrographic texture (hyaloclastites) suggests local submarine explosive sources. A more distal origin from the submerged part of the Iceland-Faeroe Ridge was proposed by Morton and Keene (1984) from chemical arguments. The subaerial part of this ridge is a likely source for the low-K rhyolitic ashes from the Vøring Plateau (Sigurdsson and Loebner, 1981). Nevertheless, some high-K rhyolitic ash levels from Rockall Plateau have high $\mathrm{Th} / \mathrm{Ta}$ ratios (Sample 81-89, Table 9 and Fig. 12) and may have 


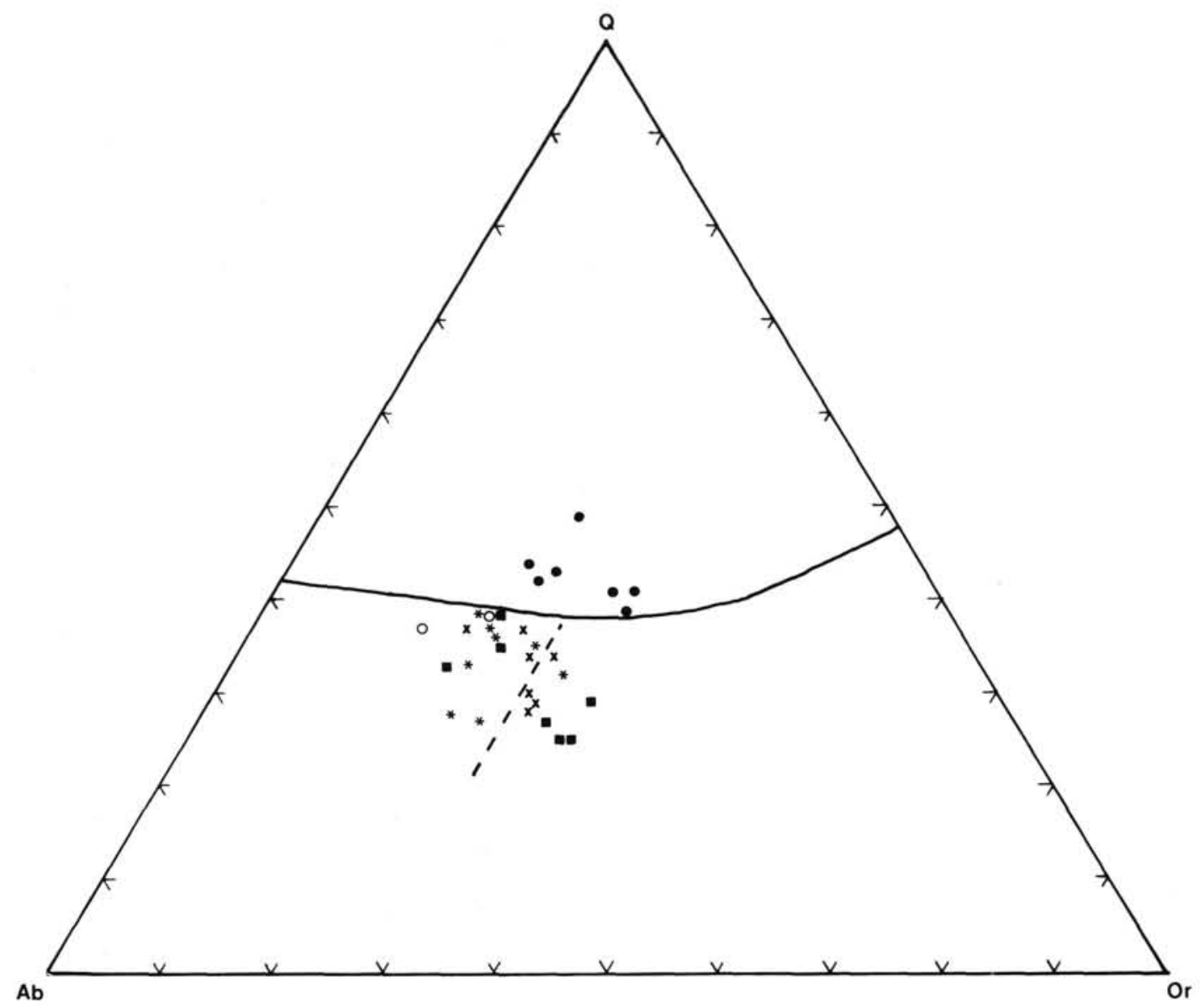

Figure 9. Normative plot of ODP Leg 104 and DSDP Legs 38 and 81 ash layers in the Q-Ab-Or diagram. Five chronologic groups of tephra layers are distinguished: Empty circle: early Eocene (DSDP Leg 81, Site 553A); Filled circles: middle Oligocene (DSDP Leg 38, Site 338) and early Miocene, 22-25 Ma (ODP Leg 104); Crosses: middle Miocene, 12-18 Ma. (ODP Leg 104 and DSDP Leg 38, Site 342); Asterisks: late Miocene, 6-9 Ma (ODP Leg 104 and DSDP Leg 38, Site 348); Filled squares: Pliocene-Pleistocene, 0-4 Ma (ODP Leg 104, DSDP Leg 38, Site 337 and Leg 81, Site 552). Dashed line: limit between the low-K and high-K groups (drawn from Sigurdsson and Loebner, 1981, Fig. 7); solid line: quartzfeldspar boundary curve for $\mathrm{PH}_{2} \mathrm{O}=1000 \mathrm{~kg} / \mathrm{cm}_{2}$ (ibid). Origin of the data: ODP Leg 104: present paper (mean analyses lacking normative corundum); DSDP Leg 81: A. Desprairies (unpublished); DSDP Leg 38: Sigurdsson and Loebner (1981).

originated from other sources, possibly the East Greenland continental margin or the British Isles.

\section{Neogene volcanic evolution (Voring Plateau)}

Three episodes of Neogene volcanic activity were recognized on the Vøring Plateau. Lower Miocene rhyolitic ash layers, mostly peralkaline, plot in the Q-Or-Ab diagram (Fig. 9) near the middle Oligocene rhyolitic horizons from DSDP Leg 38, Site 338 (Sigurdsson and Loebner, 1981). Magmatic activity occurred during middle Oligocene in the Kialineg area of the East Greenland margin. The early stage of rifting separating the continental Jan Mayen Ridge from the East Greenland margin occurred at ca. $24 \mathrm{Ma}$. This area is thus a probable source for the high-K peralkaline ashes of early Miocene age. Other types might originate from the Icelandic Platform, the building of which followed the subsidence of the Iceland-Faeroe Ridge during late Oligocene.

We propose that the two former sources remained active during the middle and late Miocene. High-K rhyolitic ash layers showing high $\mathrm{Th} / \mathrm{Ta}$ ratios (e.g., Section 104-642B-13H-CC) might originate from the continuous rifting of the continental Jan Mayen Ridge. Low-K rhyolitic ash layers and bimodal acidicbasic ash layers plot in the E-MORB field (Fig. 12) and may be derived from an Icelandic source. Finally, an Icelandic origin is compatible with all the chemical characteristics of the Pliocene and Peistocene tephra of E-MORB type or of alkali-basalt type (Sample 81-62, Table 9 and Fig. 12).

\section{ACKNOWLEDGMENTS}

The authors express their sincere thanks to Dr. Haraldur Sigurdsson for his critical review of the manuscript and to ODP staff representative Elliott Taylor for his help and advice. This study was supported by ASP - ODP France.

\section{REFERENCES}

Baker, B. H., and McBirney, A. R., 1985. Liquid fractionation. Part III: geochemistry of zoned magmas and the compositional effects of liquid fractionation. In Baker, G. H. and McBirney, A. R. (Eds.) Processes in magma chambers. J. Volcanol. Geotherm. Res., 24: 5581.

Blake, S., 1981. Eruptions from zoned magma chambers. J. Geol. Soc. London, 138: 281-287. 
Blake, S., 1984. Magma mixing and hybridization processes at the alkalic, silicic, Torfajökull central volcano triggered by tholeiitic Veidivötn fissuring, South Iceland, J. Volcanol. Geotherm. Res., 22: 1-31.

Blake, S. and Ivey, G. N., 1986. Magma mixing and the dynamics of withdrawal from stratified reservoirs. J. Volcanol. Geotherm. Res., 27: $153-178$.

Bougault, H., Joron, J. L., Treuil, M., and Maury, R. C., 1985. Local versus regional mantle heterogeneities: evidence from hygromagmaphile elements. In Bougault, H., Cande, S. C., et al., Init. Repts. $D S D P, 82$ : Washington (U.S. Govt. Printing Office), 459-482.

Donn, W. L. and Ninkovich, D., 1980. Rate of Cenozoic explosive volcanism in the North Atlantic Ocean inferred from deep sea cores. $J$. Geophys. Res., 85: 5455-5460.

Eldholm, O., Thiede, J., Taylor, E., et al., 1987. Proc. ODP, Init. Repts., 104: College Station, TX (Ocean Drilling Program).

Fisher, R. V., and Schmincke, H. U., 1984. Pyroclastic Rocks: New York (Springer-Verlag).

Flower, M. F. J., Pritchard, R. G., Brem, G., Cann, J. R., Delaney, J., Emmermann, R., Gibson, I. L., Oakley, P. J., Robinson, P. T. and Schmincke, H. U., 1982. Chemical stratigraphy, Iceland Research Drilling Project, Reydarfjordur, Eastern Iceland. J. Geophys. Res., 87, B8: 6489-6510.

Grousset, F., Joron, J. L., and Treuil, M., 1982. Identification des sources des sédiments quaternaires de la dorsale médio-atlantique (Islande-Açores) à l'aide de la géochimie des éléments de transition et des éléments hygromagmaphiles. Bull. Inst. Géol. Bassin d'Aquitaine, 31: 239-256.

Gill, J. B., 1981. Orogenic Andesites and Plate Tectonics In Minerals and Rocks, 16: New York (Springer-Verlag).

Hildreth, W., 1981. Gradients in silicic magma chambers: Implications for lithospheric magmatism. J. Geophys. Res., 86, B11: 1015310192.

Jaffrezic, H., Joron, J. L., and Treuil, M., 1977. Trace element determination in rock powder. A study of the precision for a given analytical procedure: instrumental epithermal neutron activation. J. Radioanal. Chem., 39: 185-188.

Kennett, J. P., and Thunell, R. C., 1975. Global increase in Quaternary explosive volcanism. Science, 187: 497-503.

Macdonald, R., Sparks, R. S. J., Sigurdsson, H., Mattey, D. P., McGarvie, D. W., and Smith, R. L., 1987. The 1875 eruption of Askja volcano, Iceland: combined fractional crystallization and selective contamination in the generation of rhyolitic magma. Mineral. Mag., 51: 183-202.

McGarvie, D. W., 1984. Torfajökull: A volcano dominated by magma mixing. Geology, 12: 685-688.

Mork, M.E., 1984. Magma mixing in the post-glacial Veidivötn fissure eruption, southeast Iceland: a microprobe study of mineral and glass variations. Lithos, 17: 55-75.

Morton, A. C., and Keene, J., 1984. Paleogene pyroclastic volcanism in the southwest Rockall Plateau. In: Roberts, D. G., Schnitker, D., et al., Init. Repts DSDP, 81: Washington (U.S. Govt. Printing Office), 633-643.
Nielsen, C. H., and Sigurdsson, H., 1981. Quantitative methods for electron microprobe analysis of sodium in natural and synthetic glasses. Am. Mineral., 66: 547-552.

Noe-Nygaard, A., 1974. Cenozoic to Recent volcanism in and around the North Atlantic basin. In Nairn, A.E.M., and Stehli, F. G. (Eds.)., The Ocean Basins and Margins, Vol. 2, The North Atlantic: New York (Plenum Press), 391-443.

Roberts, D. G., Schnitker, D., et al., 1984. Init. Repts DSDP, 81: Washington (U.S. Govt. Printing Office).

Sigurdsson, H., 1971. Feldspar relations in Icelandic alkalic rhyolites. Mineral. Mag., 38: 503-510.

Sigurdsson, H., and Loebner, B., 1981. Deep-sea record of Cenozoic explosive volcanism in the North Atlantic. In Self, S. and Sparks, R.S.J. (Eds.), Tephra studies: New York (Reidel. Publ. Co): 289316.

Sigurdsson, H., and Sparks, S. R. J., 1981. Petrology of rhyolitic and mixed magma ejecta from the 1875 eruption of Askja, Iceland. $J$. Petrol., 22: 41-84.

Sparks, S. R. J., Sigurdsson, H., and Wilson, L., 1977. Magma mixing: a mechanism for triggering acid explosive eruptions. Nature, 2676: 315-318.

Staudigel, H., and Hart, S. R., 1983. Alteration of basaltic glass. Mechanisms and significance for the oceanic crust-seawater budget. Geochim. Cosmochim. Acta 47: 337-350.

Sylvester, A. G., 1978. Petrography of volcanic ashes in deep-sea cores near Jan Mayen Island: Sites 338, 345-350 DSDP Leg 38. In Talwani, M., Udintsev, G., et al., Init. Repts. DSDP. Suppl. to 38, 38, 40, 41: Washington (U.S. Govt. Printing Office: 101-109).

Taylor, T. R., Vogel, T. A., and Wilband, J. T., 1980. The composite dykes at Mount Desert Island, Maine: an example of coexisting acidic and basic magmas. J. Geology, 88: 443-444.

Thompson, R. N., 1980. Askja 1875, Skye 56 Ma. Basalt triggered plinian mixed magma eruptions during emplacement of the Western Redhills Granites, Isle-of-Skye, Scotland. Geol. Res., 69: 273-307.

Vogel, T. A., 1982. Magma mixing in the acidic-basic complex of Ardnamuchan: implications on the evolution of shallow magma chambers. Contrib. Mineral. Petrol., 79: 411-423.

Wood, D. A., 1978. Major and trace element variations in the Tertiary lavas of Eastern Iceland and their significance with respect to the Iceland Geochemical anomaly. J. Petrol., 19: 393-436.

Wood, D. A., 1980. The application of a Th-Hf-Ta diagram to problems of tectonomagmatic classification and to establishing the nature of crustal contamination of basaltic lavas of the British Tertiary Volcanic Province. Earth Planet. Sci. Letters, 50:1-30.

Wood, D. A., Joron, J. L., and Treuil, M., 1979. A reappraisal of the use of trace elements to classify and discriminate between magma series erupted in different tectonic settings. Earth. Planet. Sci. Letters, 45: 326-336.

Date of initial receipt: 31 March 1987

Date of acceptance: 19 February 1988

MS 104B-120 
Table 7. Major-element analyses of bulk ashes. Atomic absorption analyses, J. Cotten, Brest, 1986. $\mathrm{Fe}_{2} \mathrm{O}_{3}$ *: total iron as $\mathrm{Fe}_{2} \mathrm{O}_{3}$. Normative parameters as in Table 6.

\begin{tabular}{|c|c|c|c|c|c|c|c|c|c|c|}
\hline $\begin{array}{l}\text { Hole } \\
\text { Core } \\
\text { Interval }(\mathrm{cm})\end{array}$ & $\begin{array}{c}642 \mathrm{~B} \\
16-02 \\
110-112\end{array}$ & $\begin{array}{c}642 C \\
21-06 \\
4-7\end{array}$ & $\begin{array}{c}642 \mathrm{~B} \\
9-03 \\
95-96\end{array}$ & $\begin{array}{l}642 \mathrm{C} \\
15-06 \\
81-82\end{array}$ & $\begin{array}{l}642 B \\
12-05 \\
84-86\end{array}$ & $\begin{array}{c}642 C \\
24-03 \\
7-8\end{array}$ & $\begin{array}{l}642 C \\
19-03 \\
71-74\end{array}$ & $\begin{array}{c}642 \mathrm{~B} \\
20-05 \\
112-113\end{array}$ & $\begin{array}{l}642 C \\
18-03 \\
21-22\end{array}$ & $\begin{array}{l}642 \mathrm{~B} \\
13 \mathrm{CC}\end{array}$ \\
\hline $\mathrm{SiO}_{2}$ & 50.80 & 51.05 & 61.25 & 65.80 & 67.00 & 67.50 & 68.00 & 69.50 & 69.80 & 70.50 \\
\hline $\mathrm{TiO}_{2}$ & 2.83 & 2.81 & 1.88 & 0.80 & 0.36 & 0.49 & 0.64 & 0.15 & 0.18 & 0.24 \\
\hline $\mathrm{Al}_{2} \mathrm{O}_{3}$ & 13.03 & 14.12 & 12.43 & 12.29 & 12.79 & 11.40 & 12.73 & 12.25 & 12.36 & 12.42 \\
\hline $\mathrm{Fe}_{2} \mathrm{O}_{3}$ & 15.02 & 13.19 & 9.67 & 5.68 & 4.54 & 5.56 & 4.95 & 3.01 & 2.93 & 2.16 \\
\hline $\mathrm{MnO}$ & 0.20 & 0.22 & 0.18 & 0.14 & 0.14 & 0.16 & 0.14 & 0.09 & 0.07 & 0.05 \\
\hline $\mathrm{MgO}$ & 3.75 & 3.48 & 2.41 & 0.82 & 0.25 & 0.23 & 0.49 & 0.05 & 0.13 & 0.14 \\
\hline $\mathrm{CaO}$ & 7.89 & 7.99 & 5.18 & 2.61 & 1.53 & 1.97 & 2.25 & 1.15 & 1.40 & 0.95 \\
\hline $\mathrm{Na}_{2} \mathrm{O}$ & 2.85 & 3.02 & 3.20 & 4.20 & 4.59 & 3.81 & 3.83 & 3.97 & 4.08 & 3.88 \\
\hline $\mathrm{K}_{2} \mathrm{O}$ & 0.94 & 1.10 & 1.90 & 3.07 & 3.49 & 2.63 & 2.50 & 3.62 & 3.14 & 4.42 \\
\hline $\mathrm{P}_{2} \mathrm{O}_{5}$ & 0.45 & 0.45 & 0.35 & 0.20 & 0.05 & 0.18 & 0.15 & 0.00 & 0.00 & 0.00 \\
\hline L.O.I. & 1.55 & 2.08 & 1.66 & 3.75 & 4.54 & 5.18 & 4.41 & 5.25 & 5.08 & 4.79 \\
\hline $\mathrm{H}_{2} \mathrm{O}^{-}$ & 0.00 & 0.02 & 0.03 & 0.07 & 0.08 & 0.00 & 0.03 & 0.10 & 0.06 & 0.00 \\
\hline TÖTAL & 99.31 & 99.53 & 100.14 & 99.61 & 99.36 & 99.11 & 100.12 & 99.14 & 99.23 & 99.55 \\
\hline Q & 6.27 & 5.87 & 19.75 & 22.79 & 22.95 & 30.71 & 29.91 & 30.45 & 31.35 & 29.55 \\
\hline Or & 5.75 & 6.74 & 11.49 & 19.03 & 21.85 & 16.62 & 15.50 & 22.87 & 19.77 & 27.61 \\
\hline $\mathrm{Ab}$ & 24.96 & 26.50 & 27.70 & 37.26 & 41.14 & 34.47 & 33.99 & 35.90 & 36.77 & 34.70 \\
\hline An & 20.70 & 22.54 & 14.28 & 5.90 & 4.24 & 6.68 & 10.67 & 5.26 & 6.55 & 3.62 \\
\hline D.I. & 36.98 & 39.11 & 58.94 & 79.08 & 85.94 & 81.79 & 79.41 & 89.22 & 87.89 & 91.86 \\
\hline S.I. & 17.64 & 17.67 & 14.70 & 6.07 & 1.99 & 1.94 & 4.29 & 0.48 & 1.29 & 1.34 \\
\hline
\end{tabular}

Table 8. Trace-element data (ppm) for bulk Leg 104 ashes. A: atomic absorption analyses, J. Cotten, Brest, 1986. N: instrumental neutron activation analyses, J.-L. Joron, Saclay, 1986.

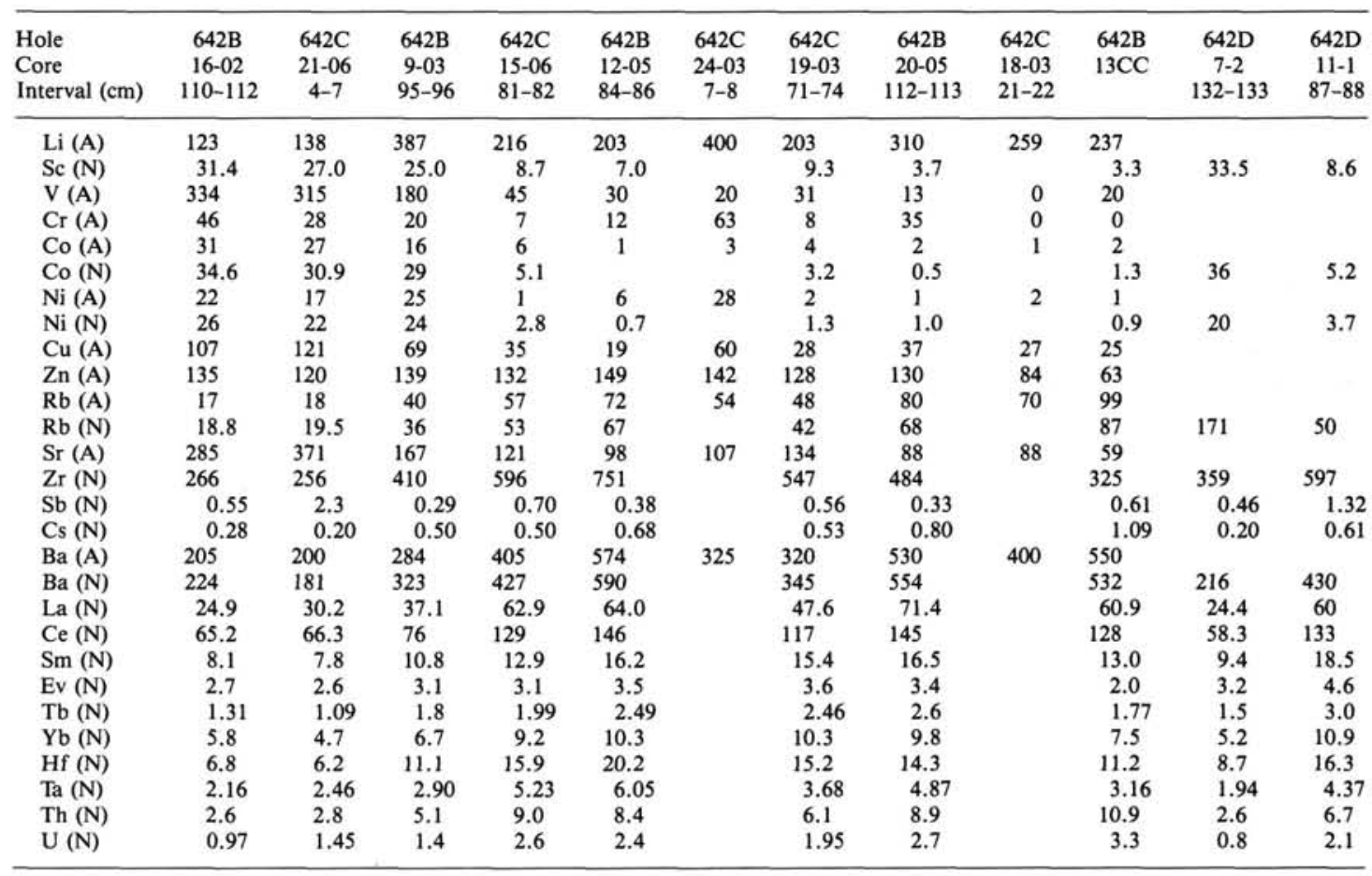




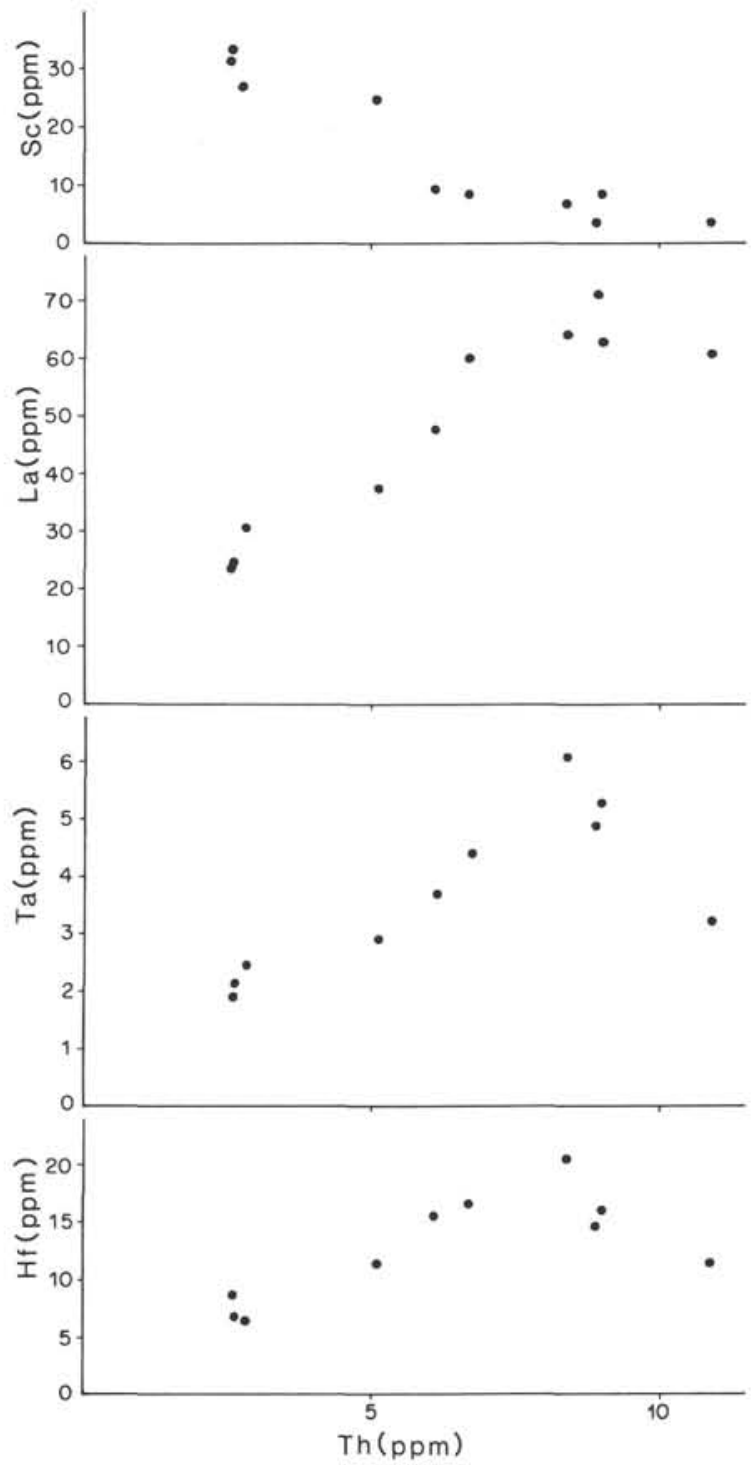

Figure 10. Scandium, lanthanum, tantalum, hafnium vs. thorium variations for bulk Leg 104 ash analyses.
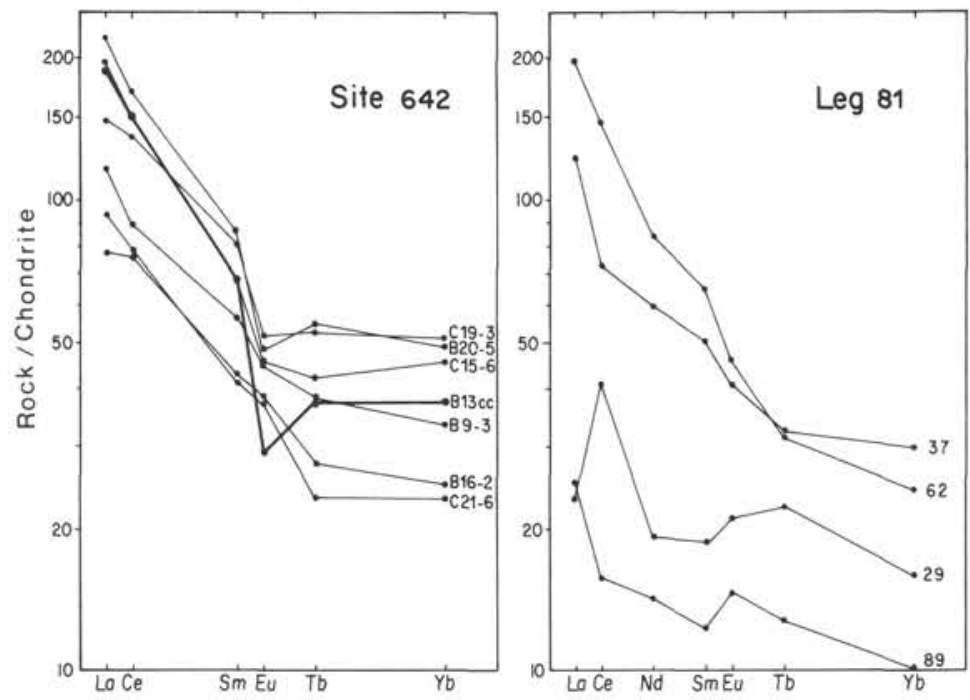

Figure 11. Chondrite-normalized REE diagrams for bulk ash analyses from Leg 104, Site 642 and Leg 81 . Normalization values according to Bougault et al. (1985). 


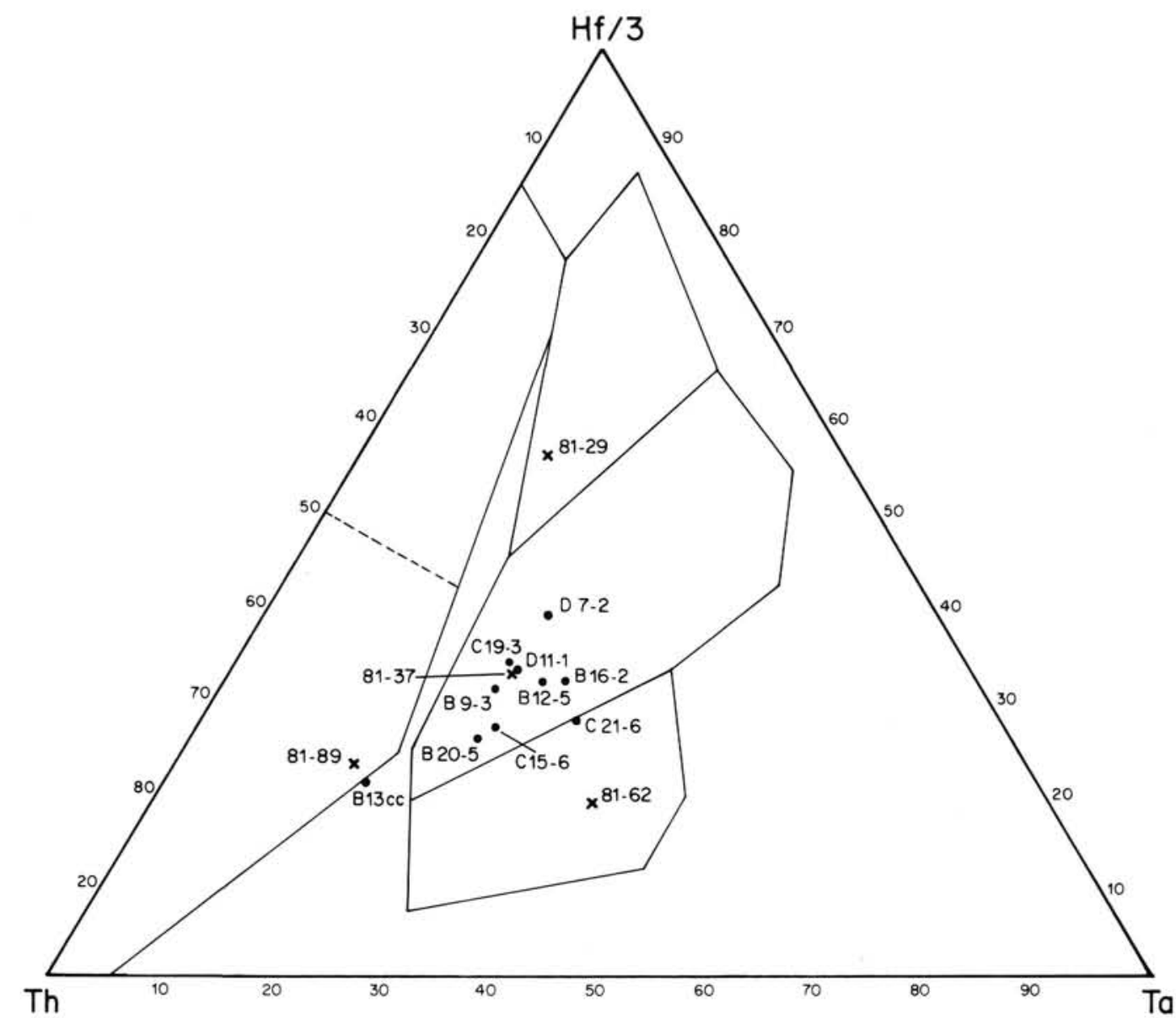

Figure 12. (Hf/3)/Th/Ta diagram following Wood (1980) and Wood et al. (1979): ODP Leg 104 bulk ash analyses (see Table 8; Site 642 samples are indicated by a letter-Hole-Core and Section); X: DSDP Leg 81 bulk ash analyses, shown for comparison.

Table 9. Trace-element data (ppm) for bulk DSDP Leg 81 ashes. Instrumental neutron activation analyses, J.-L. Joron and C. Bonnot-Courtois, Saclay, 1982. The ages of the samples are, respectively, early Eocene (No. 81-37), early-middle Eocene (No. 81-29), middle Eocene (No. 81-89) and Pleistocene (No. 81-62, K-rich rhyolite).

\begin{tabular}{|c|c|c|c|c|c|c|c|c|c|c|c|c|c|c|}
\hline Hole & Core & $\begin{array}{l}\text { Interval } \\
\text { (cm) }\end{array}$ & No. & Sc & $\mathrm{Cr}$ & Co & $\mathrm{Ni}$ & $\mathrm{Zn}$ & $\mathrm{Rb}$ & $\mathrm{Sr}$ & $\mathrm{Zr}$ & $\mathrm{Sb}$ & Cs & $\mathrm{Ba}$ \\
\hline $533 \mathrm{~A}$ & $15-2$ & $135-137$ & $81-37$ & 28.4 & 58 & 36 & 42 & 123 & 23.1 & 255 & 380 & 0.36 & 0.24 & 213 \\
\hline $553 \mathrm{~A}$ & $11-3$ & $96-98$ & $81-29$ & 42.0 & 161 & 45 & 81 & 125 & 15.7 & 317 & 188 & 0.56 & 0.17 & 61 \\
\hline $552 \mathrm{~A}$ & $38-3$ & $113-114$ & $81-89$ & 36.4 & 98 & 39 & 53 & 233 & 10.7 & 228 & 126 & 1.16 & 0.44 & 263 \\
\hline $552 \mathrm{~A}$ & $5-3$ & $135-136$ & $81-62$ & 21,4 & 55 & 16 & 9 & 284 & 62 & 342 & 462 & 0.43 & 0.80 & 580 \\
\hline
\end{tabular}

\begin{tabular}{|c|c|c|c|c|c|c|c|c|c|c|c|c|c|c|}
\hline & & & & $\mathrm{La}$ & $\mathrm{Ce}$ & $\mathrm{Nd}$ & $\mathrm{Sm}$ & $\mathrm{Eu}$ & $\mathrm{Tb}$ & $\mathrm{Yb}$ & $\mathrm{Hf}$ & $\mathrm{Ta}$ & Th & U \\
\hline $553 \mathrm{~A}$ & $15-2$ & $135-137$ & $81-37$ & 39.4 & 61.7 & 36 & 9.65 & 2.87 & 1.54 & 6.0 & 9.27 & 2.48 & 3.82 & 1.03 \\
\hline $553 \mathrm{~A}$ & $11-3$ & $96-98$ & $81-29$ & 7.4 & 35.0 & 11.5 & 3.55 & 1.50 & 1.05 & 3.2 & 3.68 & 0.38 & 0.58 & 0.52 \\
\hline $552 \mathrm{~A}$ & $38-3$ & $113-114$ & $81-89$ & 8.0 & 13.3 & 8.5 & 2.33 & 1.02 & 0.60 & 1.8 & 3.46 & 0.77 & 2.98 & 0.28 \\
\hline $552 \mathrm{~A}$ & $5-3$ & $135-136$ & $81-62$ & 63.6 & 125 & 51 & 12.5 & 3.22 & 1.50 & 4.9 & 10.6 & 7.37 & 7.53 & 2.21 \\
\hline
\end{tabular}

